\title{
Hydrologic impact of urbanization with extensive stormwater infiltration
}

Locatelli, Luca; Mark, Ole; Mikkelsen, Peter Steen; Arnbjerg-Nielsen, Karsten; Deletic, Ana; Roldin, Maria Kerstin; Binning, Philip John

Published in:

Journal of Hydrology

Link to article, DOI:

10.1016/j.jhydrol.2016.11.030

Publication date:

2017

Document Version

Peer reviewed version

Link back to DTU Orbit

Citation (APA):

Locatelli, L., Mark, O., Mikkelsen, P. S., Arnbjerg-Nielsen, K., Deletic, A., Roldin, M. K., \& Binning, P. J. (2017). Hydrologic impact of urbanization with extensive stormwater infiltration. Journal of Hydrology, 544, 524-537. https://doi.org/10.1016/j.jhydrol.2016.11.030

\section{General rights}

Copyright and moral rights for the publications made accessible in the public portal are retained by the authors and/or other copyright owners and it is a condition of accessing publications that users recognise and abide by the legal requirements associated with these rights.

- Users may download and print one copy of any publication from the public portal for the purpose of private study or research.

- You may not further distribute the material or use it for any profit-making activity or commercial gain

- You may freely distribute the URL identifying the publication in the public portal 


\section{Hydrologic impact of urbanization with extensive stormwater infiltration}

Article in Journal of Hydrology · November 2016

DOI: 10.1016/j.jhydrol.2016.11.030

CITATIONS

9

7 authors, including:

Luca Locatelli

Technical University of Denmark

13 PUBLICATIONS 116 CITATIONS

SEE PROFILE

Peter Steen Mikkelsen

Technical University of Denmark

187 PUBLICATIONS 3,037 CITATIONS

SEE PROFILE
Ole Mark

DHI Group

80 PUBLICATIONS 1,052 CITATIONS

SEE PROFILE

Karsten Arnbjerg-Nielsen

Technical University of Denmark

123 PUBLICATIONS $\mathbf{1 , 8 8 0}$ CITATIONS

SEE PROFILE

Some of the authors of this publication are also working on these related projects:

Project Urban Flood Risk Management: Implementation of the 3 Points Approach View project

Project $\quad$ Master View project 


\section{Accepted Manuscript}

Research papers

Hydrologic impact of urbanization with extensive stormwater infiltration

Luca Locatelli, Ole Mark, Peter Steen Mikkelsen, Karsten Arnbjerg-Nielsen, Ana Deletic, Maria Roldin, Philip John Binning

PII:

S0022-1694(16)30736-3

DOI: http://dx.doi.org/10.1016/j.jhydrol.2016.11.030

Reference:

HYDROL 21644

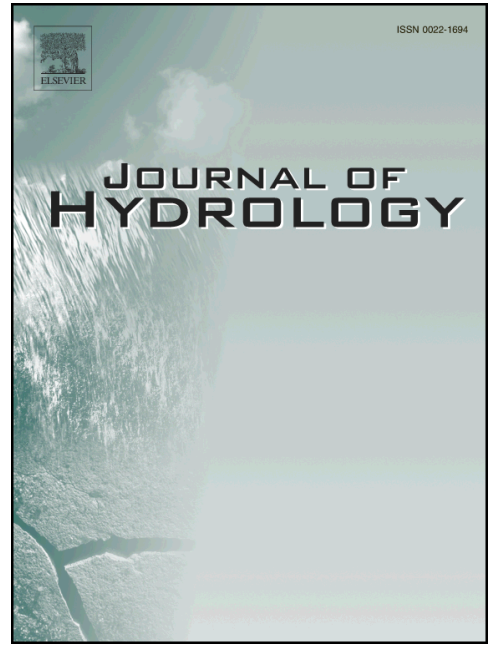

To appear in:

Journal of Hydrology

Received Date:

31 August 2016

Revised Date:

11 November 2016

Accepted Date:

15 November 2016

Please cite this article as: Locatelli, L., Mark, O., Steen Mikkelsen, P., Arnbjerg-Nielsen, K., Deletic, A., Roldin, M., John Binning, P., Hydrologic impact of urbanization with extensive stormwater infiltration, Journal of Hydrology (2016), doi: http://dx.doi.org/10.1016/j.jhydrol.2016.11.030

This is a PDF file of an unedited manuscript that has been accepted for publication. As a service to our customers we are providing this early version of the manuscript. The manuscript will undergo copyediting, typesetting, and review of the resulting proof before it is published in its final form. Please note that during the production process errors may be discovered which could affect the content, and all legal disclaimers that apply to the journal pertain. 


\section{Hydrologic impact of urbanization with extensive stormwater infiltration}

Luca Locatelli $^{\mathrm{a}}$, Ole Mark ${ }^{\mathrm{b}}$, Peter Steen Mikkelsen ${ }^{\mathrm{a}}$, Karsten Arnbjerg-Nielsen ${ }^{\mathrm{a}}$, Ana Deletic ${ }^{\mathrm{c}, \mathrm{d}}$, Maria Roldin $^{\mathrm{e}}$, Philip John Binning ${ }^{\mathrm{a}}$

a) Technical University of Denmark, Dept. of Environmental Engineering, Bygningstorvet, Building 115 , 2800 Kgs Lyngby, Denmark

b) DHI, Agern Allé 5, 2970 Hørsholm, Denmark

c) Department of Civil Engineering, Monash University, Clayton, VIC 3800, Australia

d) Cooperative Research Centre for Water Sensitive Cities, Monash University, Clayton, VIC 3800, Australia

e) DHI, Honnörsgatan 16, Växjö, Sweden

Corresponding author: Luca Locatelli

E-mail: $\underline{l u l o @ e n v . d t u . d k}$

Tel: +4545251432

ABSTRACT 
This paper presents a novel modeling analysis of a 40-year-long dataset to examine the impact of urbanization, with widespread stormwater infiltration, on groundwater levels and the water balance of a watershed. A dataset on the hydrologic impact of urbanization with extensive stormwater infiltration is not widely available, and is important because many municipalities are considering infiltration as an alternative to traditional stormwater systems. This study analyzes groundwater level observations from an urban catchment located in Perth, Western Australia. The groundwater observation data cover approximately a 40-year-long period where land use changes (particularly due to urbanization) occurred; moreover, the monitored area contains both undeveloped and urbanized areas where stormwater infiltration is common practice via soakwells (shallow vertical infiltration wells). The data is analyzed using a distributed and dynamic hydrological model to simulate the groundwater response. The model explicitly couples a soakwell model with a groundwater model so that the performance of the soakwells is reduced by the increase of groundwater levels. The groundwater observation data is used to setup, calibrate and validate a coupled MIKE SHE-MIKE URBAN groundwater model and the model is used to quantify the extent of groundwater rise as a result of the urbanization process. The modeled urbanization processes included the irrigation of new established private and public gardens, the reduction of evapotranspiration due to a decrease in green areas, and the development of artificial stormwater infiltration. The study demonstrates that urbanization with stormwater infiltration affects the whole catchment water balance, increasing recharge and decreasing evapotranspiration. These changes lead to a rise in the groundwater table and an increase in the probability of groundwater seepage above terrain.

\section{INTRODUCTION}

Stormwater infiltration through infiltration trenches, swale-trench systems, infiltration areas, permeable pavements, rain gardens and bioretention basins is part of Water Sensitive Urban Design (WSUD) (Fletcher et al., 2015) which aims at improving urban stormwater management and building more livable and resilient urban environments that are adapted to future uncertainties caused by climate change (Wong and Brown, 2009). 
Stormwater infiltration (rather than stormwater drainage pipe systems) increases groundwater recharge and groundwater levels (Jeppesen, 2010; Göbel et al., 2004) which can cause an increased risk of groundwater seepage above terrain, decreased infiltration capacity of stormwater infiltration systems, and an increase of water flowing into foundation drains and infiltrating sewer systems (Antia, 2008; Endreny and Collins, 2009). This is particularly important in areas with shallow water tables, where even modest increases in groundwater levels can cause the water table to rise to the ground surface, causing groundwater flooding.

The implementation of stormwater infiltration in an urban area is constrained by existing built environment and underground infrastructures, soil pollution, groundwater levels, local drinking water assets, and the quality of the stormwater runoff (Göbel et al., 2004; Mikkelsen et al., 1994; Revitt et al., 2003). It is important to predict the consequences of stormwater infiltration on subsurface flows and the interaction with underground structures (Dietz et al., 2007). This requires an understanding of the mutual interaction between infiltration devices and groundwater (Bouwer, 2002). To predict the impact of WSUD systems (WSUDs) hydrological models are often used (Elliott et al., 2007).

Several studies have analyzed the impact of stormwater infiltration on infiltration rates, groundwater mounding and groundwater table focusing on the impact of single systems. Duchene et al. (1994) presented a numerical model based on Richards'equation to simulate infiltration from infiltration trenches. Bouwer (2002) described the main processeses affecting the performance of different infiltration systems, and Guo (1998) presented a steady-state surface-subsurface model to design trench infiltration basins. Dussaillant et al. (2004) presented a three layer model with subsurface flow described by Richards equtions for designing rain gardens, while Browne et al. $(2008 ; 2012)$ presented a one-dimensional and a two-dimensional model to calculate infiltration rates from stormwater infiltration systems and Thompson et al. (2010) used the software HYDRUS-2D to predict the water-table mounding beneath infiltration basins. Carleton (2010) simulated the effect of local stormwater infiltration on local groundwater mounding. Roldin et al. (2013) presented a model to predict infiltration rates and groundwater mounding 
from single soakaways. Bergman et al. (2011) and Warnaars et al. (1999) reported the performance of observed infiltration trenches in an urban area, and Machusick et al. (2011) presented the groundwater observations from an experimental stormwater infiltration basin on a shallow unconfined aquifer

The larger scale impact of widespread stormwater infiltration has been examined by several authors. Markussen et al. (2004) modelled the impact of rain gardens on a 50 ha catchment in Denmark, and concluded that annual combined sewer overflow volume could be reduced by $75-85 \%$. Roldin et al. (2012a) modelled the impact of widespread stormwater infiltration through soakaways on a $3 \mathrm{~km}^{2}$ catchment in Denmark and concluded that annual combined sewer overflow volume could be reduced by 24-68\%; Petersen et al. (1994) modeled theoretical catchments with stormwater infiltration; Xiao et al. (2007) modeled a real neighborhood scale and Peters et al. (2007) modeled the city scale. These studies showed that stormwater infiltration can reduce stormwater runoff and combined sewer overflows, and that the efficiency of infiltration systems is greatly influenced by the soil characteristics.

Several studies have modelled the behaviour of infiltration units in urban areas. Manglik et al. (2004) presented a model to simulate the aquifer response to time varying recharge and pumping from multiple basins and wells. Elliott et al. (2009) analyzed the effect of aggregation of single storm-water control devices in an urban catchment model. Antia (2008) presented a model to predict the infiltration rates, mounding and seepage zones resulting from the interaction between multiple infiltration devices; he also reported cases in the UK where infiltration devices caused unexpected downstream flooding. Endreny and Collins (2009) used the software MODFLOW to predict the impact of different spatial arrangements of infiltatration units on stormwater recharge and groundwater mounding for a 8 ha catchment in New York, they predicted a water table rise of $1.1 \mathrm{~m}$ after 30 years of recharge through bioretention basins. Maimone et al. (2011) used the softwere DYNFLOW to predict the effect of widespread stormwater infiltration in Philadelphia. Ku et al. (1992) modeled the impact of widespread stormwater infiltration basins on Nassau County, New York and concluded that recharge would increase by up to $12 \%$ and the groundwater table would rise up to $1.5 \mathrm{~m}$ compared to a traditional scenario without stormwater 
infiltration. Jeppesen (2010) modeled the impact of widespread storm water infiltration in Copenhagen concluding that it would lead to a surface near groundwater table and require increased groundwater drainage. Göbel et al. (2004) modeled the effect of stormwater infiltration on the groundwater table of an $11.5 \mathrm{~km}^{2}$ semi-urban catchment. Kidmose et al. (2015) modeled the impact of stormwater infiltration scenarios on groundwater levels and stream flows in Silkeborg in Denmark. Barron et al. (2013a, 2013b) quantified the impact of urbanization and stormwater infiltration on the hydrological water balance in the Southern River catchment in Western Australia.

\subsection{Problem identification}

This paper addresses two gaps in the literature. Firstly, while some studies have used models to predict the hydrologic impact of urbanization with widespread stormwater infiltration, none of the models have been calibrated against observation data from an urbanized catchment with stormwater infiltration. In fact, data sets including groundwater level observations in a large catchment undergoing urbanization with extensive stormwater infiltration are not currently available in the literature. Secondly, there is a lack of studies where shallow groundwater levels affect the infiltration from WSUDs, and the two-way coupling between groundwater and the infiltration devices is explicitly modeled (Roldin 2012a). Most of the published literature simulates catchment scale stormwater infiltration without explicitly modelling the interaction of groundwater levels with the stormwater infiltration systems (Maimone et al., 2011; Göbel et al., 2004; Barron et al., 2013a and 2013b).

\subsection{Aim of the paper}

This paper presents the development of an urban hydrologic model that was calibrated and validated using groundwater observation data from an urban area where widespread stormwater infiltration has been practiced for decades and which has been subject to major land use changes. The data set is from a subcatchment in Perth, Western Australia, where groundwater level data has been collected since 1960. Since that time, the area has been progressively urbanized, and so the dataset is ideal for analyzing the 
hydrologic impact of urbanization with stormwater infiltration. The area is particularly interesting because of the widespread implementation of direct stormwater infiltration. Groundwater flooding is a problem in the area, and there is a suspicion that its incidence has increased as a consequence of urbanization and stormwater infiltration. The aim of this paper is to analyze the catchment scale hydrologic impact of urbanization with stormwater infiltration. This was done by fitting an integrated hydrological model to a groundwater observations dataset from Perth and by simulating the groundwater response during different land use scenarios. The model was used to analyze 1) the changes in groundwater levels, 2) the changes in the hydrologic balance and 3) the performance of soakwells in areas with a shallow groundwater table. The novelty of this paper is the use of groundwater head observations from a large catchment with gradual urbanization including widespread stormwater infiltration. The study illustrates some of the long term issues arising from urbanization that may lead to increased urban stormwater infiltration and changes in evapotranspiration and irrigation supplied to new developed areas.

\section{THE STUDY AREA}

The study area is located in the south of Perth (Western Australia) and covers an area of about $112 \mathrm{~km}^{2}$

(Figure 1). The area is mainly flat with topographical heights ranging between 0 and $35 \mathrm{~m}$ above Australian Height Datum (AHD) and is characterized by mild terrain slopes $(<0.5 \%)$. 


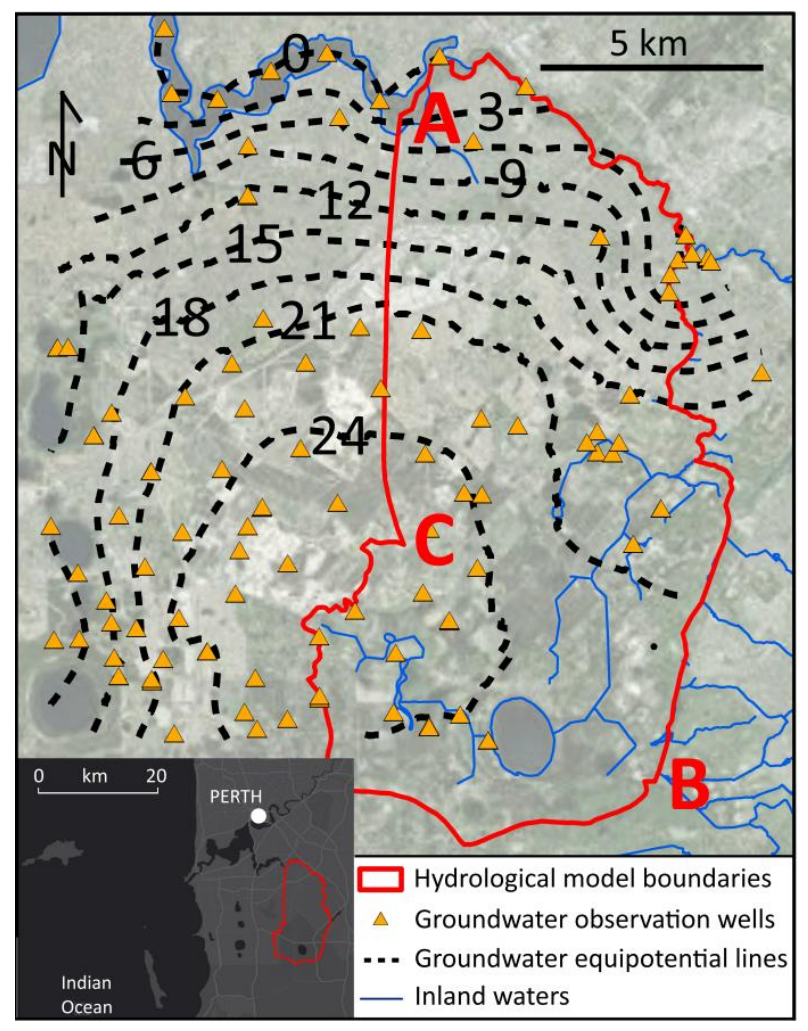

Figure 1. Plan view of the model area with the groundwater equipotential lines (in meters) of the unconfined superficial aquifer based on average observed heads in the period 2008-2014. The groundwater equipotential lines cover a larger area compared to the model area to allow definition of the model boundary C-A which corresponds to a groundwater streamline. The background of the image is an aerial photo.

The area has a Mediterranean climate with very dry summers and wet winters. The mean annual rainfall was $852 \mathrm{~mm}$ in the period 1980-2014. However, the south-west of the Western Australia region has experienced up to $20 \%$ decrease in average annual rainfall since the mid-1970s (Department of Water, 2007) and the mean annual rainfall was $775 \mathrm{~mm}$ in the period 2004-2014. Up to $80 \%$ of the annual precipitation occurs during the cooler period between May and September.

The quaternary geology of the area is comprised of sandy aeolian formations with interbedded clay layers (Barron et al., 2013a). The exposed surface of the sand coincides with the Aeolian Bassendean Dune System of McArthur and Bettenay (1960). These sandy formations have a thickness up to $30 \mathrm{~m}$ and form an unconfined aquifer referred to as a Superficial Aquifer which lies on top of confining sedimentary rocks of Cretaceous age (Davidson, 1995). The unconfined groundwater table fluctuates annually up to 2 $\mathrm{m}$ and is less than 6 meters below the terrain level in the model area. 
Urbanization in Perth includes the construction of roads, houses and pavements and is commonly coupled with open areas (such as wetlands and green parks) to help manage urban stormwater. Public Open Spaces (POS) and private gardens require irrigation from November to April and the water is mainly sourced from local groundwater resources (Barron et al., 2013a). It is common practice in the area to locally infiltrate stormwater runoff from roofs and roads into the very permeable soil (Davidson, 1995). Infiltration of roof stormwater runoff is conducted through soakwells, underground concrete tanks that receive stormwater runoff from roofs and infiltrate it to the subsurface (See Figure 2). Road runoff is diverted to local constructed lakes/wetlands. During regular rainfall events (with less than 1 year return period) the surface runoff from most regions of the catchment will drain to the locally constructed lakes/wetlands.

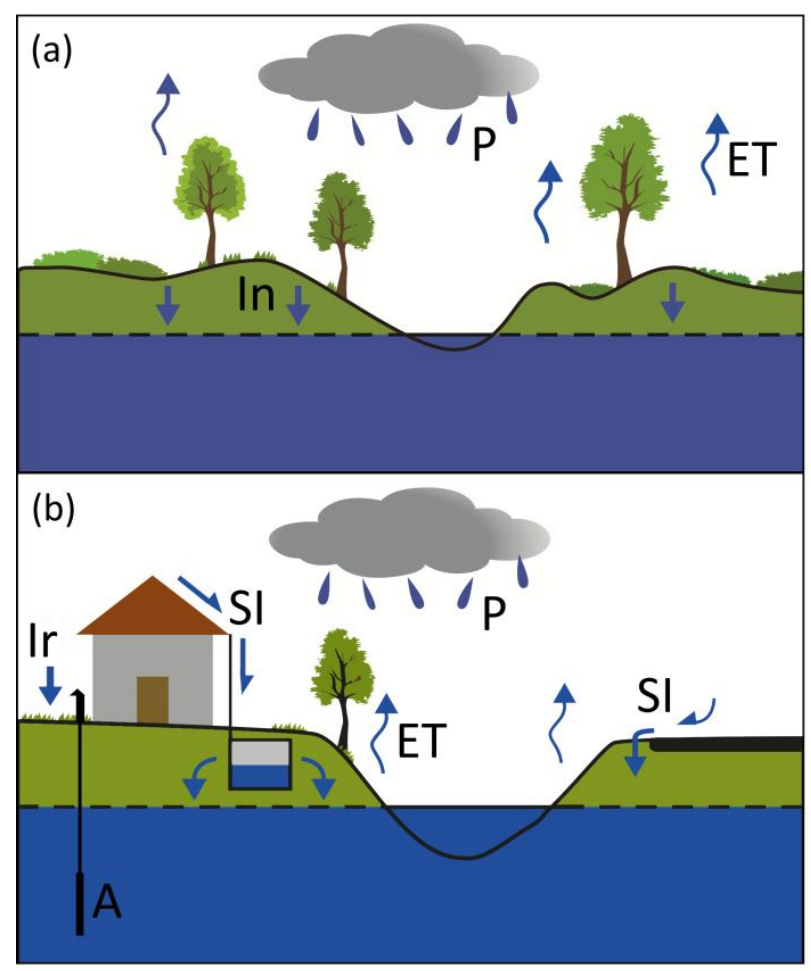

Figure 2. Conceptual model. (a) Undeveloped areas. (b) Urbanized area: roof runoff is diverted into soakwells and road runoff is locally infiltrated, leading to an increasing groundwater table and a reduction of evapotranspiration. P=precipitation; ET=evapotranspiration; In=infiltration; SI=stormwater infiltration; Ir=irrigation; A=abstraction.

Building practices for soakwells and other local stormwater systems in the area of Perth are found in the Stormwater Management Manual for Western Australia (Department of Water, 2004-2007). 
Some of the Department of Water's recommendations for stormwater management approaches include:

- $\quad$ Keep water in the landscape where appropriate. This can be partly achieved by managing small rainfall event runoff from constructed impervious surfaces at the runoff source.

- $\quad$ Retain native vegetation wherever possible when assessing urban development proposals.

- Include vegetation (especially trees) within drainage management systems wherever possible, e.g. in streetscapes, car parks, parks and around civic buildings and squares.

This paper builds on several previous studies of the groundwater of the Perth area. Davidson (1995), Salama et al. (2005) and McArthur and Bettenay (1960) described the geology and water balance of groundwater systems in Perth with models and measurements. Barr and Barron (2009) and Barron et al (2013a and 2013b) presented a hydrogeological model to predict the impact of urbanization on groundwater and the water balance. Botte (2012) and JDA Consultant Hydrologists (2015) presented water level and infiltration data from single soakwells, and Ocampo et al. (2006) analyzed the groundwater response after single rainfall events. Here a new hydrogeological model of the area is constructed, with the main addition to the previous work being the explicit description of the spatially distributed soakwell systems and the hydrological response over decades-long time period.

\section{METHODOLOGY}

\subsection{Hydrological model}

This study uses the software MIKE SHE-MIKE URBAN (DHI, 2012a; DHI, 2013) to set up a physicallybased distributed hydrological model. The MIKE SHE tool simulates the processes of interception, ponding, evapotranspiration, overland flow, infiltration and unsaturated and saturated flow. Streamflow is computed by MIKE 11 (DHI, 2012b). The MIKE URBAN model was used to simulate the water level and the infiltration processes of soakwells. The rainfall falling on rooftops is diverted into soakwells and the rainfall falling on roads and other impervious areas is locally infiltrated in the model. The two models are fully coupled, employing smaller times steps in the MIKE URBAN model and interacting with each other at each MIKE SHE time step. 
The model was built after interpreting the available data on geology, rainfall etc. The data for the model was provided by DoW (the Western Australia Department of Water), and is described in a series of reports (Department of Water, 2004, 2004-2007, 2009 and 2013). The following describes the model setup, with reference to previous when it was employed in model setup.

\section{Model grid and boundaries}

The groundwater model simulates part of the superficial unconfined aquifer, with the model area being shown in Figure 1. The boundary conditions for the model are as follows:

- A-B. Head dependent boundary. A river is simulated along this boundary with vertical cross sections perpendicular to the river flow direction being interpolated from the digital elevation model (The digital elevation model shown in Figure $3 \mathrm{~d}$ is based on a LiDAR survey conducted in February 2008 when the streams along this boundary were mostly dry. This allowed to interpolate vertical cross sections of the river bed perpendicular to the stream flow direction and to simulate a river along this boundary). The roughness parameter of the stream was manually calibrated based on water level and stream-flow observations collected at a measuring station along the river (station number: 616092. Figure 3c). This boundary describes a part of the Canning River, Southern River and Wungong Brook. These streams can have seasonal fluctuations up to $2 \mathrm{~m}$ and Wungong Brook may dry out during dry years (Barron et al., 2013a). In order to analyze the model sensitivity to the A-B boundary condition a fixed groundwater head boundary condition (Dirichlet boundary condition) with the head corresponding to the height of terrain map along the A-B line of Figure 1 was tested. The Dirichlet boundary produced an insignificant difference in the modeled groundwater heads compared to the head dependent boundary, therefore the applied head dependent boundary was assumed to be reasonable.

- B-C. No-flow boundary corresponding to the Southern river catchment delineation provided by the Department of Water (the catchment delineation was based on digital elevation model 
analysis). This boundary condition has also been employed in other groundwater studies of the area (Barr and Barron, 2009 and Barron et al., 2013a).

- C-A. No-flow boundary corresponding to a groundwater streamline obtained from groundwater equipotential lines interpolated from averaged observation heads in the period 2008- 2014. The equipotential lines are shown in Figure 1 and are similar to those reported by Davidson(1995). Point $\mathrm{C}$ and about $5 \mathrm{~km}$ of model boundary (see Figure 1) are in the region where the groundwater head is above $24 \mathrm{~m}$. Point $\mathrm{C}$ has the highest groundwater head along the groundwater streamline C-A. The groundwater streamline C-A was selected in order to reduce the area of the unconfined aquifer to be modeled (and still include all the areas of interest).

The bottom of the model (Figure 1) is set as a no-flow boundary, except for the south-eastern part of the model where a downward leakage was specified equal to $2 \%$ of the incoming annual rainfall. The estimate of the extent of the leaking area and the specified discharge to the underlain Leederville Aquifer was obtained from Davidson (1995).

The MIKE SHE model grid size was set to be $70 \times 70 \mathrm{~m}^{2}$. Barr and Barron (2009) showed that such grid size represents the majority (>92\%) of the landscape depressions in the Southern River catchment (a larger area compared to the actual case study area) so that landforms are assumed to be adequately represented. The time step of the groundwater flow model (MIKE SHE) was set to be an adjustable time step with a maximum 3 hours.

The hydrological model includes different layers to simulate the superficial aquifer (Figure 4). The geological model of the area was developed by analyzing the lithology data from 314 boreholes and was verified against the larger scale geological model of Davidson (1995). The top layer was assigned a thickness of $3 \mathrm{~m}$, with properties corresponding to the two superficial soil types (Bassendean sand and clay) mapped in the area (Figure 3a). A similar top layer thickness was applied in the hydrogeological model of Barr and Barron (2009) for a nearby catchment in Perth. Soil properties were modified in order to account for the effect of macropores and fractures in the soil structure due to the built environment 
and/or plant/tree roots. Layer 2 represents the sandy unconfined upper aquifer (Bassendean Sand). Layer 3 is a clayey aquitard and is modeled as a uniform thickness layer. In reality this layer is believed to be discontinuous and comprised of clay lenses (Davidson, 1995). Layer 4 represents the sandy sediments (Bassendean Sand) at the bottom of the superficial aquifer. Clay lenses creating localized perched groundwater tables are known to be widespread in the superficial aquifer. But these lenses were not explicitly simulated and instead the properties of the layer were described in the model by effective bulk parameters.
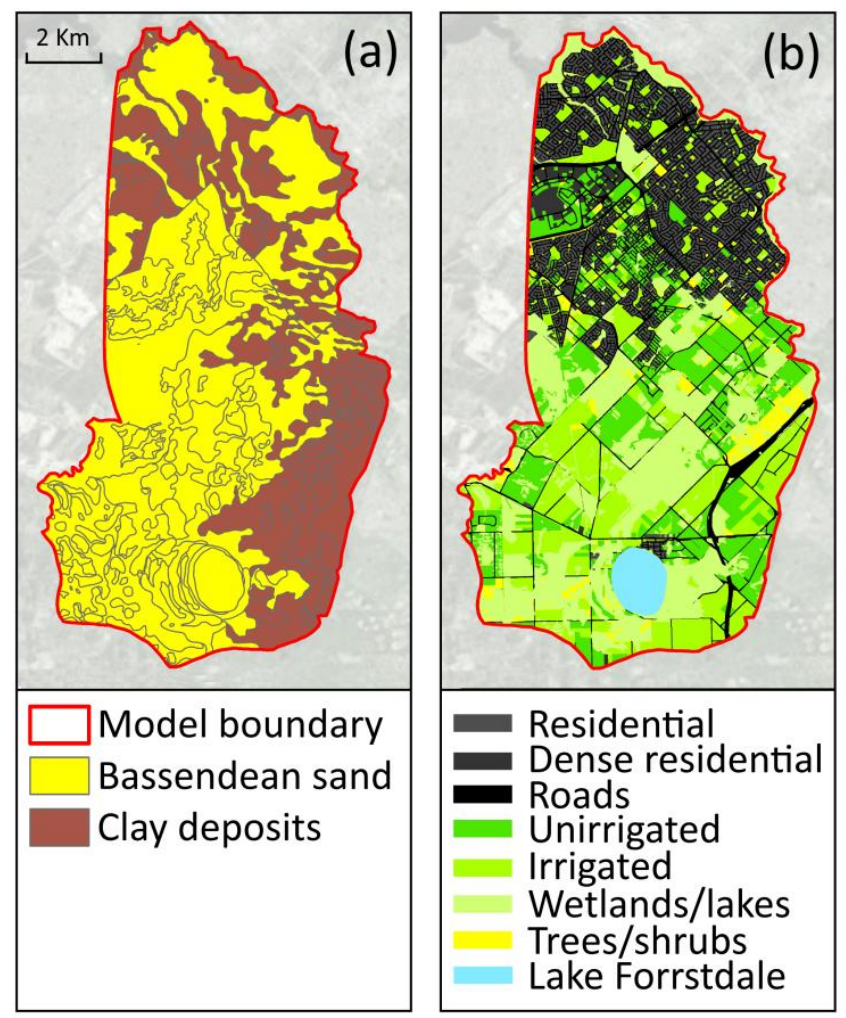

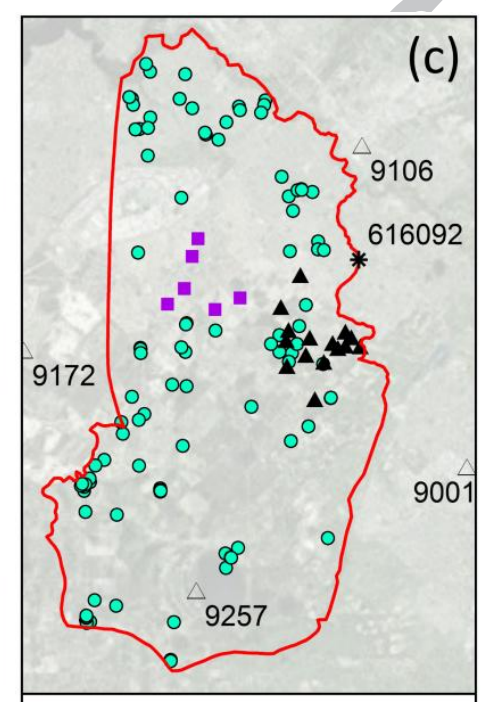

* Stream gauge Weather station

- SR wells (GW)

- Long term obs. wells

- CoG wells (GW)

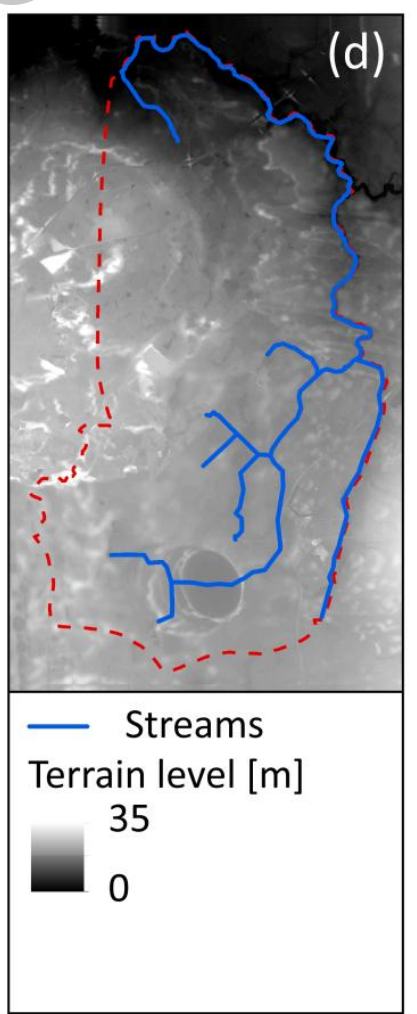

Figure 3. (a) Surface geology. (b) Land use in 2005. (c) Observation data; stream flow, weather variables, groundwater heads (GW). SR corresponds to Southern River wells and CoG corresponds to City of Gosnell wells. (d) Digital elevation model and modeled streams. 

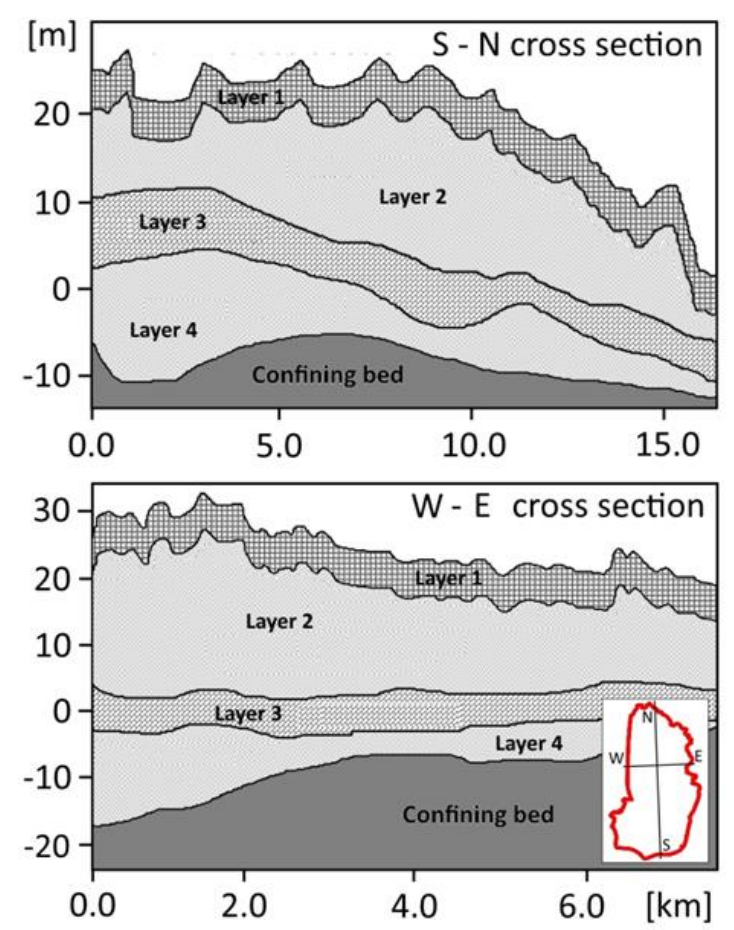

Figure 4. Cross sections of the geological model. Layer 1 is made of spatially distributed (according to the surface geology map of Figure 3a) sand and clay; Layer $\mathbf{2}$ is sand; Layer $\mathbf{3}$ is clay and Layer $\mathbf{4}$ is sand.

\section{Stormwater infiltration systems - soakwells}

Soakwells were implemented in MIKE URBAN where they were represented as leaky "links" (normally used to represent pipes) (DHI, 2012a). The time step of the MIKE URBAN model was set to $600 \mathrm{~s}$. Residential houses can have up to 3-4 soakwells and their storage volume and geometry can vary depending on local municipality requirements. Information about construction details of local soakwells is limited. Multiple soakwells were modeled as a single aggregated unit as proposed by Elliot et al. (2009) and Roldin et al. (2012b). 798 aggregated soakwells were simulated within the model area. Soakwells were applied to the land use categories of 'Residential' and 'Dense Residential/Commercial'. The geometry of each aggregated soakwell was chosen to be $1.5 \mathrm{~m}$ wide (B) and $1 \mathrm{~m}$ deep (H) and the length (L) determined as a function of the drainage area as shown in Eq. (1):

$L=\frac{A \cdot C \cdot r}{B \cdot H}$ 
where $A$ is the total area, $C$ is the fraction of the total residential (or dense residential/commercial) area $A$ connected to soakwells, and $r$ is the storage depth of soakwells (i.e. the rainfall depth to be managed by the soakwells). $r$ is assumed to be equal to $15 \mathrm{~mm}$ which is the typical storage depth for soakwells in the area. The value of $C$ was set to be 0.40 for "dense residential/commercial" areas and 0.35 for "residential" areas (these values are similar to those of Barron et al., 2013a).

The modeled soakwells were spatially located at the centroids of the corresponding area as shown on Figure 5 and were placed $20 \mathrm{~cm}$ below the terrain level. The exchange of water between soakwells and groundwater depends on the computed heads at the soakwell point location; this makes the spatial location an influential factor for the performance of the soakwells. The smaller the residential area $A$, the better the centroid represents local groundwater conditions. Groundwater gradients in the area are less than $0.5 \%$. Spatial errors in model results due to soakwell aggregation were minimized by restricting residential catchments to an extent of less than 100-400 m in length (and width). The aggregated soakwell areas had a size of 0.4-1.5 ha in the central part of the model area whereas in the model areas close to the northern and north-eastern boundary they had an average size of about 3 ha. Coarser discretization in the boundary areas was necessary in order to reduce computational time to an acceptable level. The coupled MIKE SHE-MIKE URBAN model runs about 10 times slower when compared to the single MIKE SHE model. The model running time was about $1 \mathrm{~h}$ per simulation year using 4 processors of $2.1 \mathrm{GHz}$ each. 


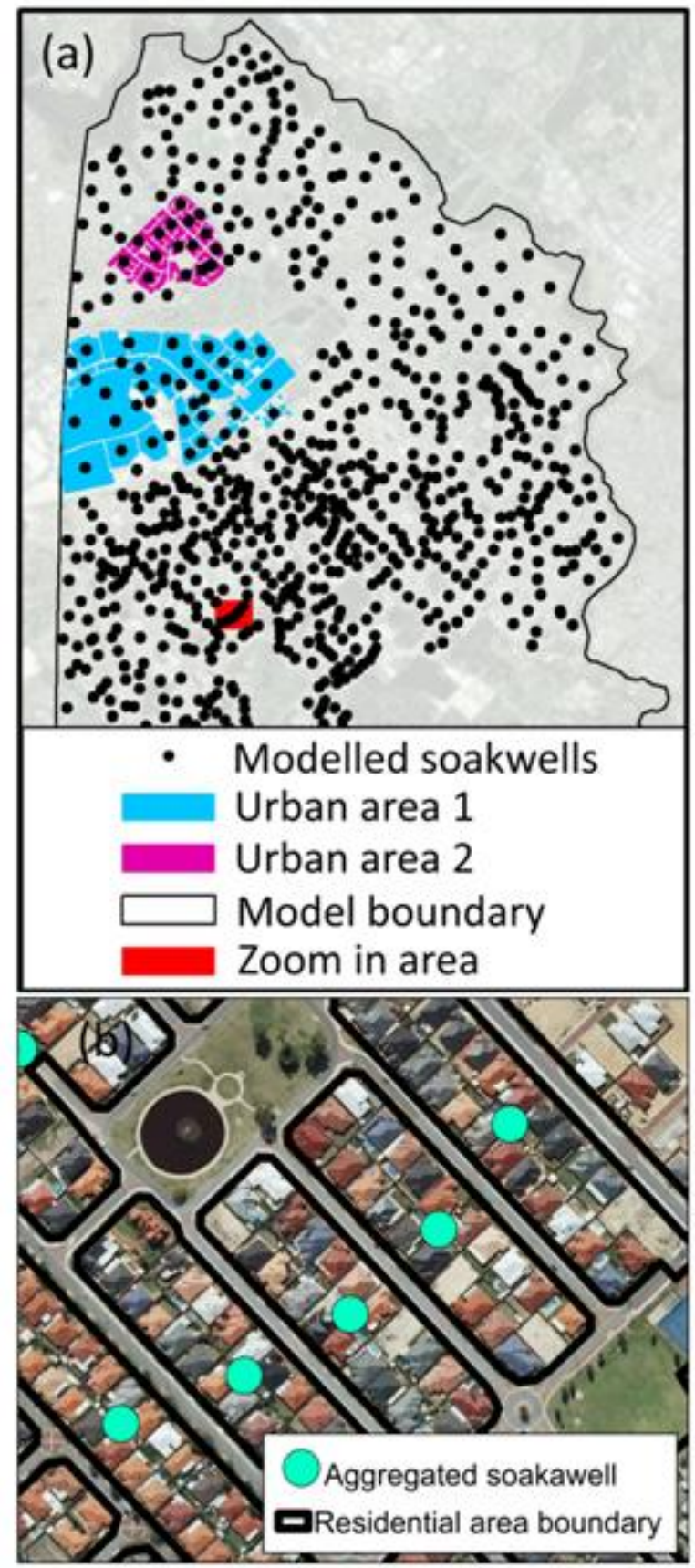

Figure 5. (a) Soakwells in the model area together with selected urban areas for which results are highlighted in the following. (b) Zoomin on part of the area shown on (a).

Soakwells infiltrate water if the groundwater head is lower than the water level in the soakwells, otherwise there is no infiltration. If the water level in the soakwell exceeds its capacity, overflow to the corresponding MIKE SHE cell occurs. The soakwells infiltrate stormwater runoff according to the following equation:

$Q_{\text {inf }}=C_{L} \cdot W A \cdot h$ 
Where $C_{L}\left[\mathrm{~s}^{-1}\right]$ is the leakage coefficient (DHI, 2013), WA $\left[\mathrm{m}^{2}\right]$ is the wetted area of the soakwell and $h$ $[\mathrm{m}]$ is either the water level in the soakwell if the groundwater level is below the bottom of the soakwell or the difference between the water level in the soakwell and the groundwater level if the groundwater is above the bottom of the soakwell. The value of $C_{L}$ was set to $2 \cdot 10^{-4} \mathrm{~s}^{-1}$. This value was obtained by trialand-error calibration that aimed at having most of the soakwell storage (> 60\%) emptied within a day. Observed data from single soakwells in the area showed that soakwells empty within a couple of days and that most of the storage is restored after a day (Botte et al., 2012). Further tests on soakwells at a property (JDA Consultant Hydrologists, 2015) showed that soakwells could infiltrate all the $65.6 \mathrm{~mm}$ of water applied to the roof of the house in 12 hours (corresponding to a 10 year return period event). The infiltration model equation (Eq. 2) shows that $Q_{\text {inf }}$ tends to 0 as the water level $h$ in the soakwell approaches 0 , meaning that the modeled soakwells do not ever empty. This model was originally developed for simulating the interaction of sewer pipes with groundwater; more specific infiltration models for infiltration systems are available in the literature (Roldin et al., 2012a) but were not available in the actual model interface.

\section{Rainfall, evapotranspiration, abstraction and irrigation}

A daily rainfall time series was available at 4 different weather stations with locations shown in Figure $3 \mathrm{c}$ (station numbers: $9172,9106,9001$ and 9257). The spatial variability of rainfall is low and so the time series were spatially distributed using Thiessen polygons around the stations (the difference in the measured annual precipitation between the different stations was on average $7 \%$ ).

Pan evaporation data had a daily time step (measured at station 9172, see Figure 3c) and was used in the model as potential evapotranspiration. The spatial variability of potential evapotranspiration fluxes was assumed to be negligible. Actual evapotranspiration was computed in MIKE SHE using the "2-Layer Water Balance Method" (DHI, 2013). This method is particularly suited for areas with a shallow groundwater table (Kristensen and Jensen, 1975). This model simulates the processes of interception, ponding, recharge and evapotranspiration, assuming the unsaturated zone to consist of two "layers" 
representing average conditions in the unsaturated zone. The vegetation parameters used in the model are the Leaf Area Index (LAI), the root depth (RD) and the crop coefficient (Kc) and are summarized in Table 2. The parameter values selected were similar to those of Barron et al. (2013a) and they were manually calibrated (see the calibration section) in order that the annual fluxes were similar to those of other studies in the same area. The vegetation parameters (LAI, RD and $\mathrm{Kc}$ ) have seasonal variation with the lowest values in January, February and March and the highest values in June, July, August and September. The winter peak in these parameters is due to the fact that plant growth occurs in the winter (June, July, August and September) when the climate is wetter (Potential evapotranspiration has a seasonal variation with the highest values in January, February and March and the lowest values in June, July, August and September). The infiltration/evaporation parameters varied spatially with land use. An example of the land use data employed in one of the modeling scenarios is shown in Figure $3 b$ (the colors of this figure were mainly chosen to show the urbanized and the undeveloped areas). The soil parameters used to model the unsaturated zone processes include the infiltration capacity, the soil moisture contents at the wilting point, field capacity and saturation. These parameters are shown in Table 2 and are similar to those in the geological study of the Perth area of Salama et al. (2005).

Groundwater abstraction data was provided by the Department of Water for 7 wells in the model area (average abstraction of approximately $2 \cdot 10^{5} \mathrm{~m}^{3} /$ year per well). A constant irrigation flux from October to April was applied to the land use categories of "residential areas", "dense residential" and "irrigated". Table 1 summarizes the modeled irrigation fluxes together with the corresponding source. For example, the "residential" areas in the model required an irrigation flux of $17 \mathrm{~mm} / \mathrm{m}^{2} /$ week (provided by DoW, the Western Australia Department of Water) applied to the irrigated area which was estimated (together with the DoW) to be $30 \%$ of the "residential area", resulting in a uniform modeled irrigation flux of 5.1 $\mathrm{mm} / \mathrm{m}^{2} /$ week over the whole residential area. This flux is partially (30\%) sourced from the superficial aquifer and modeled as abstraction from shallow boreholes, with the remainder (70\%) being sourced from the distribution network (Department of Water, 2009) and being included in the model as additional rainfall. 
Table 1. Modelled irrigation fluxes.

\begin{tabular}{|l|l|l|l|l|}
\hline Land use category & $\begin{array}{l}\text { Required } \\
\text { irrigation flux }\end{array}$ & Source (modelled) & $\begin{array}{l}\text { Estimated } \\
\text { irrigated area }\end{array}$ & $\begin{array}{l}\text { modelled } \\
\text { irrigation flux }\end{array}$ \\
\hline & $\mathrm{mm} / \mathrm{m}^{2} /$ week & $\begin{array}{l}\text { \% of the } \\
\text { whole area }\end{array}$ & mm $/ \mathrm{m}^{2} /$ week \\
\hline irrigated & 25 & $100 \%$ external (modeled as added rainfall) & 70 & 17.5 \\
\hline residential & 17 & $\begin{array}{l}30 \% \text { from superficial aquifer (local shallow wells) } \\
\text { and 70\% external (modeled as added rainfall) }\end{array}$ & 30 & 5.1 \\
\hline $\begin{array}{l}\text { dense residential/ } \\
\text { comerciall }\end{array}$ & 17 & $\begin{array}{l}5 \% \text { from superficial aquifer (local shallow wells) } \\
\text { and 95\% external (modeled as added rainfall) }\end{array}$ & 20 & 3.4 \\
\hline
\end{tabular}

The use of a constant irrigation flux (with low intensity) rather than multiple single irrigation events (with higher intensity) is likely to overestimate the evapotranspiration (Barron et al., 2013a).

\section{Model calibration and validation}

Observed groundwater head time series from observation wells are available from both urbanized and undeveloped areas (Figure 3c). The groundwater observations wells were divided into three different groups: City of Gosnell ( $\mathrm{CoG})$ wells are located within a recently urbanized area where daily observations were recorded in the period 2010-2011; Southern River (SR) wells are located within lightly urbanized and undeveloped areas and have daily observations in the period 2012-2014; long term observation wells are located throughout the model area and have time steps in the range of 2-12 months and discontinuous observations between 1970 and 2015.

Model calibration was performed for the groundwater heads in the period 2010-2012 using the software Autocal (AutoCal, 2012) which employs a global optimization algorithm based on the 'Population Simplex Evolution method'. The objective function to be minimized is shown in Eq. (3).

$\sum_{j=1}^{n}$ RMSE $_{j}$

where $n$ is the number of observation wells, $j$ represents the code of each observation well and $R M S E_{j}$ is the root mean-square-error at each well defined by:

$R M S E_{j}=\sqrt{\frac{1}{N} \sum_{i=1}^{N}\left(H_{o b s, j, i}-H_{s i m, j, i}\right)^{2}}$ 
where $\mathrm{N}$ is the number of groundwater level observations at different times $i$ for each well $j, H_{o b s, j, i}$ is the observed groundwater head and $H_{m o d, j, i}$ is the simulated groundwater head at the $\mathrm{i}$-th observation in the time series for the $\mathrm{j}$-th observation well. Notice that (3) implies that each well is assigned the same weight. The automatically calibrated parameters were the hydraulic conductivity of the geological layers, the specific yield and the storativity. The parameters to be calibrated were selected after performing a local sensitivity analysis and examining the parameter correlation of a preliminarily calibrated model.

The model was calibrated for 2 years (2010 and 2011) using a 1 year warm-up period (1 year of warm-up was judged to be sufficient due to the highly permeable sediments and the somewhat limited catchment area). The initial conditions of the calibration model (the initial water and groundwater levels) were based on the results of a preliminary calibration of the model. 25 observation wells were used for the modle calibration and validation (see the calibration wells in Figure 6).

Validation was performed for the years 2005-2010 and 2012-2014. The land use varied in the model during the calibration and validation periods and had 2 different configurations, one from 2005-2008 and one from 2008-2014.

The root mean square error (RMSE), the mean error (ME), the scaled root mean square (SRMS) and the mean absolute error (MAE) were computed to evaluate the performance of the simulated groundwater heads (Anderson and Woessner, 1992).

Only groundwater head observations were used in the objective function of the automatic calibration (stream flow dynamics were not part of the automatic calibration). Nevertheless, the simulated mean annual groundwater recharge and the mean annual stream flow were similar to the catchment water balance results of Barr and Barron (2009) and Barron et al. (2013a) for a nearby catchment. Annual recharge and stream flow fluxes were adjusted by trial-and-error calibration of LAI, root depth, crop coefficient and the leakage coefficient of the stream beds. Calibration of hydrological models commonly involves the use of multi-objective functions that aggregate both observed heads and stream flows with user defined weights. These objective functions are quite complex and the choice of weights is an 
ongoing discussion. For example Kidmose et al., (2015) employed higher weights for groundwater heads compared to stream flow observations in their multi-objective function; Jeppesen (2010) first calibrated for heads and subsequently stream flow; Stisen et al. (2010) showed in their case study that, apart from redistribution of internal flow processes like base flow, drain flow, and overland flow, only minor changes occurred in spite of the major change in the multi-objective function weights. The calibration method employed in this paper is consistent with the approaches employed in these studies. The focus on groundwater levels in the calibration is also consistent with the aim of the model to simulate groundwater levels.

\subsection{The modeling scenarios}

The calibrated and validated model was used to run different scenarios. All the simulated scenarios presented in this paper are based on continuous simulations of the period 1995-2014. The year 1994 is used as warm-up period and the initial conditions (the initial water and groundwater levels) for each scenario are taken from the results of a simulation run with the corresponding scenario parameters. The model parameters are shown in Table 2 unless otherwise specified. Each scenario considers one constantin-time land use coverage, selected from the historical data in the catchment. 5 model scenarios are considered:

(1) 2012 scenario (s2012) with land use data from 2012. The 2012 land use had $37 \%$ of the area urbanized (urbanized areas are counted by summing the land use categories of 'Roads',

'Residential' and 'Dense residential').

(2) 1994 scenario (s1994) with land use data from 1994. The 1994 land use had $23 \%$ of the area urbanized.

(3) 1974 scenario (s1974) with land use data from 1974. The 1974 land use had $16 \%$ of the area urbanized. 
(4) No groundwater scenario (No_GW). This scenario decouples soakwells from groundwater levels so that infiltration from soakwells is not limited by the groundwater levels. This scenario is run using the land use of 2012.

(5) Stormwater draining infrastructure (sDrain). This scenario assumes that stormwater runoff from roofs is diverted into stormwater drain pipes (stormwater runoff from roads is still locally infiltrated). This is modeled by removing roof stormwater runoff from the model area. This scenario is run using the land use of 2012. Stormwater runoff would be typically discharged into a receiving water. The consequences of this were not addressed, e.g. frequent channel forming flows in the receiving systems which negatively affect the ecology and geomorphology of the receiving system.

Many factors influence groundwater levels. For instance, climate and rainfall patterns clearly influence groundwater response. Land use also affects groundwater response and data was available for the catchment with time intervals between 3 and 10 years. In the scenarios, we focus exclusively on evaluating the impact of land-use on groundwater levels. This means that all other factors are identical between the scenarios, and only land-use is varied.

\subsection{The analyzed model outputs}

\section{Water balance}

The impact of urbanization and stormwater infiltration on the water balance was presented by comparing the model outputs of the different scenarios both at the whole catchment scale and on the selected area shown in Figure 5b (approximately 16 ha). The selected water balance components are defined as follows: 'soakwell infiltration' is the amount of water infiltrated through the soakwells; 'baseflow to rivers' is the total amount of baseflow to the modeled rivers; 'pumping' is the amount of abstraction from the model area; 'net recharge' is the water that is exchanged between the unsaturated and the saturated zone (it is the difference between the water reaching the uppermost groundwater table and the water leaving the uppermost aquifer due to evapotranspiration) (positive net recharge means that the water 
volume reaching the uppermost groundwater table is higher than the water leaving the uppermost aquifer due to evapotranspiration, and vice versa); 'irrigation' is the amount of water applied to the model surface' and 'total ET' is the total amount of evapotranspiration.

\section{Soakwell performance}

The performance of soakwells is presented in the results section in terms of the ratio between the inflow stormwater runoff volume and the overflow from soakwells over a simulation period. The inflow and outflow volumes were calculated for two selected urban areas (Urban area 1 and 2; see figure 5). These urban areas are approximately 500 ha each and were selected since they had a constant land use throughout the different simulation scenarios.

\section{Groundwater rise}

The groundwater rise in the results section was calculated from the annual maximum simulated groundwater levels at a point location. The annual hydrological year was assumed to coincide with the calendar year. Annual maximums were sorted and a return period calculated according to the Weibull (1939) plotting position:

$$
T=\frac{y+1}{r}
$$

where $y$ is the duration of the time series in years and $r$ is the rank of the annual maximum groundwater level.

\section{Water above terrain}

Simulated surface water levels at the Auckland Parade detention basin (located near the 'zoom in area' of Figure 5a) are shown in the results section. This basin is located within a residential area and aerial photos showing water above terrain levels are available for some days in the year 2010 .

\section{RESULTS}

\subsection{Model calibration and validation}


Table 2 shows the fixed, the dependent ('Tied' in the table) and calibrated model parameters and their values. The values of the calibrated hydraulic conductivity and storage coefficients for the sandy layer of the superficial aquifer (Layer 2) are similar to those of Barr and Barron (2009). 


\begin{tabular}{|c|c|c|c|c|}
\hline & Parameter & Value & Unit & Description \\
\hline نَّ & $\begin{array}{l}\mathrm{K}_{\mathrm{h} 2} \\
\mathrm{~K}_{\mathrm{h} 4} \\
\mathrm{~S}_{\mathrm{y} 1 \text { sand }} \\
\mathrm{S}_{\mathrm{S} 2} \\
\mathrm{~S}_{\mathrm{S} 3} \\
\mathrm{~S}_{\mathrm{y} 1 \text { clay }} \\
\mathrm{S}_{\mathrm{S} 4} \\
\end{array}$ & $\begin{array}{l}4.3 \mathrm{E}-4 \\
3.8 \mathrm{E}-4 \\
0.28 \\
3.0 \mathrm{E}-5 \\
1.2 \mathrm{E}-4 \\
0.099 \\
4.0 \mathrm{E}-5 \\
\end{array}$ & $\begin{array}{l}\mathrm{m} / \mathrm{s} \\
\mathrm{m} / \mathrm{s} \\
- \\
- \\
- \\
- \\
-\end{array}$ & $\begin{array}{l}\text { Horizontal hydraulic conductivity of Layer } 2 \\
\text { Horizontal hydraulic conductivity of Layer } 4 \\
\text { Specific yield of the sand in Layer } 1 \\
\text { Specific storage of Layer } 2 \\
\text { Specific storage of Layer } 3 \\
\text { Specific yield of the clay in Layer } 1 \\
\text { Specific storage of Layer } 4\end{array}$ \\
\hline 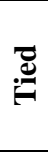 & $\begin{array}{l}\mathrm{K}_{\mathrm{V} 2} \\
\mathrm{~K}_{\mathrm{V} 4} \\
\mathrm{~S}_{\mathrm{y} 2} \\
\mathrm{~S}_{\mathrm{S} 1 \text { sand }}\end{array}$ & $\begin{array}{l}=\mathrm{K}_{\mathrm{h} 2} / 10 \\
=\mathrm{K}_{\mathrm{h} 4} / 10 \\
=\mathrm{S}_{\mathrm{y} 1 \text { sand }} \\
=\mathrm{S}_{\mathrm{S} 2}\end{array}$ & $\begin{array}{l}\mathrm{m} / \mathrm{s} \\
\mathrm{m} / \mathrm{s} \\
- \\
-\end{array}$ & $\begin{array}{l}\text { Vertical hydraulic conductivity of Layer } 2 \\
\text { Vertical hydraulic conductivity of Layer } 4 \\
\text { Specific yield of Layer } 2 \\
\text { Specific storage of the sand in Layer } 1\end{array}$ \\
\hline & $\begin{array}{l}\mathrm{K}_{\mathrm{h} 1 \text { Sand }} \\
\mathrm{K}_{\mathrm{V} 1 \text { Sand }} \\
\mathrm{K}_{\mathrm{h} 1 \text { Clay }} \\
\mathrm{K}_{\mathrm{V} 1 \text { Clay }} \\
\mathrm{K}_{\mathrm{h} 3} \\
\mathrm{~K}_{\mathrm{V} 3} \\
\text { ManningN } \\
\text { Detention_storage } \\
\text { Leakage } \\
\text { Capillary_fringe }\end{array}$ & $\begin{array}{l}5.0 \mathrm{E}-4 \\
5.0 \mathrm{E}-5 \\
5.0 \mathrm{E}-5 \\
5.0 \mathrm{E}-6 \\
1.0 \mathrm{E}-5 \\
1.0 \mathrm{E}-6 \\
6-100 \\
2 \\
1 \mathrm{E}-4 \\
0.3\end{array}$ & $\begin{array}{l}\mathrm{m} / \mathrm{s} \\
\mathrm{m} / \mathrm{s} \\
\mathrm{m} / \mathrm{s} \\
\mathrm{m} / \mathrm{s} \\
\mathrm{m} / \mathrm{s} \\
\mathrm{m} / \mathrm{s} \\
\mathrm{m}^{1 / 3} / \mathrm{s} \\
\mathrm{mm} \\
\mathrm{m} / \mathrm{s} \\
\mathrm{m}\end{array}$ & $\begin{array}{l}\text { Horizontal hydraulic conductivity of the sand in Layer } 1 \\
\text { Vertical hydraulic conductivity of the sand in Layer } 1 \\
\text { Horizontal hydraulic conductivity of the clay in Layer } 1 \\
\text { Vertical hydraulic conductivity of the clay in Layer } 1 \\
\text { Horizontal hydraulic conductivity Layer } 3 \\
\text { Vertical hydraulic conductivity of Layer } 3 \\
\text { Spatially distributed Manning Number for overland flow } \\
\text { Detention storage for overland flow } \\
\text { Leakage coefficient of stream beds } \\
\text { Depth of the capillary fringe (spatially uniform) }\end{array}$ \\
\hline 总 & $\begin{array}{l}\text { Land use } \\
\text { Unirrigated area } \\
\text { Irrrigated area } \\
\text { Roads } \\
\text { Dense urban/ } \\
\text { commercial } \\
\text { Urban residential } \\
\text { Wetlands } \\
\text { Trees/ shrubs } \\
\text { Lake Forrestdale }\end{array}$ & $\begin{array}{l}0.2-1.0 \\
0.3-0.7 \\
0.5-0.9 \\
0.7-1.0 \\
0.3-0.7 \\
0.5-0.9 \\
0.1 \\
0 \\
0.1 \\
0.2-0.7 \\
0.3-0.5 \\
0.4-0.5 \\
0.2-0.7 \\
0.3-0.5 \\
0.4-0.5 \\
0.2-1.0 \\
0.3-0.7 \\
0.5-0.9 \\
1.2 \\
2.0 \\
0.8 \\
0 \\
0 \\
0.9\end{array}$ & $\begin{array}{l}\mathrm{m} \\
- \\
- \\
\mathrm{m} \\
- \\
- \\
\mathrm{m} \\
- \\
- \\
\mathrm{m} \\
- \\
- \\
\mathrm{m} \\
-\end{array}$ & $\begin{array}{l}\text { LAI } \\
\text { Root Depth } \\
\text { Kc } \\
\text { LAI } \\
\text { Root Depth } \\
\text { Kc } \\
\text { LAI } \\
\text { Root Depth } \\
\text { Kc } \\
\text { LAI } \\
\text { Root Depth } \\
\text { Kc } \\
\text { LAI } \\
\text { Root Depth } \\
\text { Kc } \\
\text { LAI } \\
\text { Root Depth } \\
\text { Kc } \\
\text { LAI } \\
\text { Root Depth } \\
\text { Kc } \\
\text { LAI } \\
\text { Root Depth } \\
\text { Kc }\end{array}$ \\
\hline & $\begin{array}{l}\text { Unsaturated soil } \\
\text { properties } \\
\text { Clay water content } \\
\text { Sand water content } \\
\text { Clay } \\
\text { Sand }\end{array}$ & $\begin{array}{l}0.45 ; 0.33 ; 0.15 \\
0.38 ; 0.16 ; 0.03 \\
6.0 \mathrm{E}-5 \\
6.0 \mathrm{E}-4\end{array}$ & $\begin{array}{l}-;-;- \\
-;-;- \\
\mathrm{m} / \mathrm{s} \\
\mathrm{m} / \mathrm{s}\end{array}$ & $\begin{array}{l}\text { Saturation; field capacity; wilting point } \\
\text { Saturation; field capacity; wilting point } \\
\text { Saturated hydraulic conductivity of superficial clay } \\
\text { Saturated hydraulic conductivity of superficial sand }\end{array}$ \\
\hline
\end{tabular}

Table 3 shows the RMSE, MAE, SRMS and ME for the calibration and validation period and Figure 6 shows the ME for selected wells in the calibration period. Figure 7 shows the simulated and observed 
time series of groundwater heads for 4 calibration wells selected to illustrate the observed range of model fits.

The simulated annual groundwater net recharge during the period 2009-2014 was 19\% of the annual rainfall over the whole model area (the mean annual rainfall in this period was $728 \mathrm{~mm}$ ), $0 \%$ of the annual rainfall in the undeveloped areas of the model and $48 \%$ of the annual rainfall in the urbanized areas.

The net recharge can be compared with other estimates from literature using a similar definition of net recharge. Groundwater net recharge over the model area was estimated by Davidson (1995) to spatially vary between 0 and $24 \%$ of the annual rainfall, with an average of about 15\%; Allen (1976) estimated about 5.5\% net recharge to the unconfined aquifer south of Perth; Sharma and Pionke (1984) estimated $12 \%$ of net recharge over native bushland, and stated that beneath a mature pine plantation there may be no groundwater net recharge; Barron et al. (2013a) reported a net recharge of $1 \%$ of the annual rainfall for an undeveloped area in the Southern River catchment (the Southern River catchment is a larger area that also includes a part of the actual model area). Uncertainties in the amount of recharge over the area are not addressed in this paper.

The simulated contribution to stream flow from the whole model area in the period 2009-2014 was $16 \%$ of the incoming rainfall. Barr and Barron (2009) reported an average annual contribution to streams in the Southern river catchment of $6 \%$ of the incoming rainfall. Barron et al. (2013a) reported a contribution of $11 \%$ of the incoming rainfall for the whole Southern River Catchment; $1 \%$ for the Wungong Urban Waters (a circa $20 \mathrm{~km}^{2}$ area close to the south-eastern boundaries of our model area), and 28-37\% for urbanized areas in the Southern river catchment. 


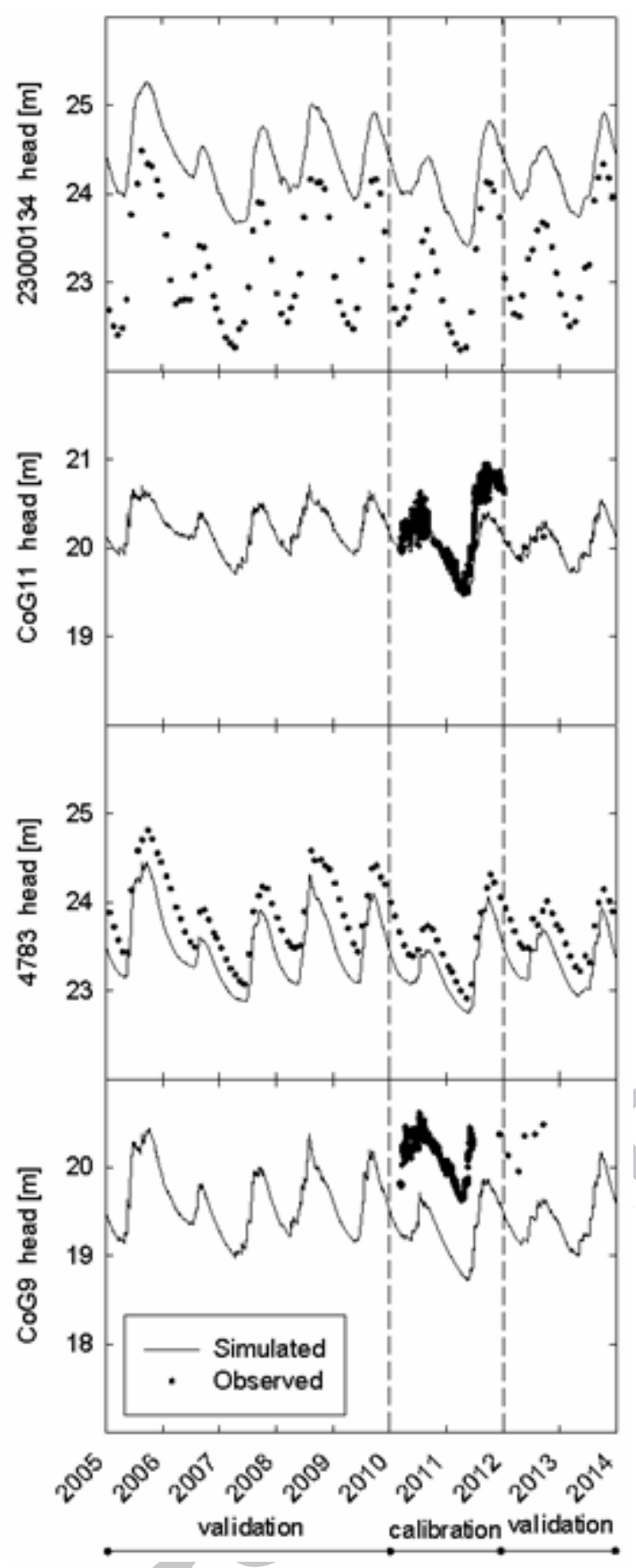

Figure 7. Simulated and observed groundwater head at selected

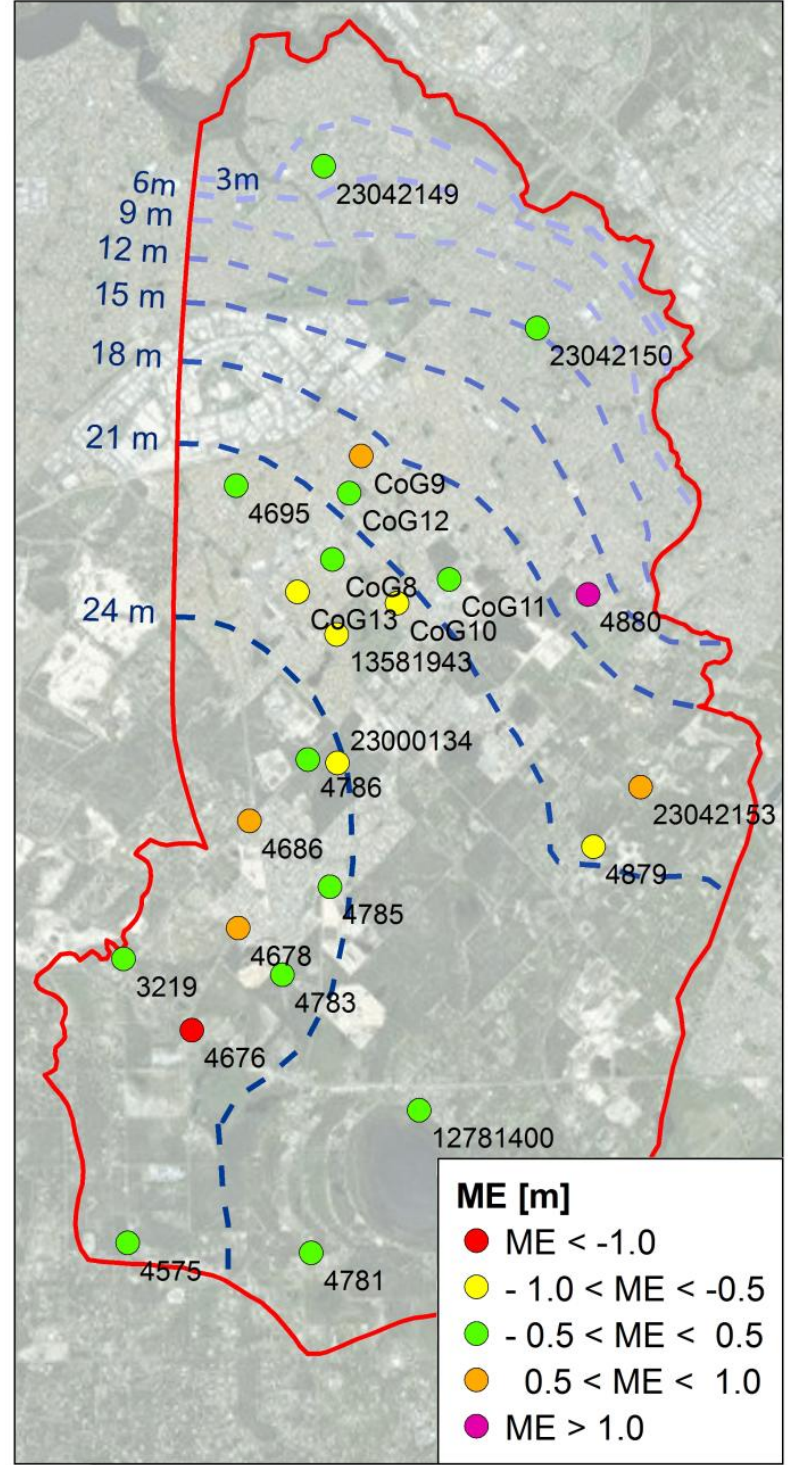

Figure 6. Mean Error (ME) of the calibration wells during the calibration period. The dashed lines represent the mean groundwater equipotential lines during the calibration period.

observation wells for the calibration and validation period.

Table 3. Calibration and validation performance measures. Root mean square error (RMSE), mean error (ME), scaled root mean square (SRMS) and mean absolute error (MAE).

\begin{tabular}{|l|l|l|l|l|l|}
\hline & Period & RMSE [m] & SRMS [\%] & ME [m] & MAE [m] \\
\hline Calibration & $2010-2012$ & 0.67 & 1.5 & 0.037 & 0.63 \\
\hline Validation & $2005-2010$ & 0.74 & 1.7 & -0.25 & 0.68 \\
& $2012-2014$ & 0.71 & 1.6 & 0.027 & 0.67 \\
\hline
\end{tabular}




\subsection{Water balance}

Figure 8 a shows the water balance for the whole catchment as a function of the different scenarios. The process of urbanization with stormwater infiltration (from the scenario s1974 to s1995 to s2012) leaded to increased 'soakwell infiltration', 'pumping' and 'irrigation'. Increasing stormwater infiltration furthermore lead to an increased 'net recharge' and an increased 'baseflow to rivers', and the increased 'net recharge' lead to groundwater rise (see Section 3.4). The 'total ET' decreases with increasing urbanization because of the reduction of green areas. Similar trends were also reported by Barron et al. (2013a; 2013b) for a similar area in Perth.

Figure $8 \mathrm{~b}$ shows the water balance of the area shown in Figure $5 \mathrm{~b}$ for the scenarios s1974, where most of the area was 'unirrigated' and 'trees/shrubs'; s1995, where $1 \%$ of the unirrigated area of s1974 was turned into residential; and s2012 where most of the area was turned into 'roads' and 'residential'. Figure $8 \mathrm{~b}$ shows more pronounced water balance changes compared Figure 8a because the focus area was heavily urbanized between s1995 and s2012. Surprising, the 'net recharge' decreased and the 'total ET' increased between s1974 and s1995. This is because in this specific area there was an insignificant difference in land use between the s1974 and the s1995 (only 1\% difference in urbanization), whereas in the whole catchment significant urbanization took place (from 16\% urbanized in s1974 to 23\% in s1995). Increased urbanization in other parts of the catchment increased the overall catchment groundwater levels which resulted in an increased 'total ET' from shallow groundwater in this area. The scenario s2012 shows a significant increase of 'net recharge' and decrease of 'total ET', mainly due to stormwater infiltration and the reduction of green areas.

Overall results show that urbanization with stormwater infiltration lead to an increased recharge, mainly due to stormwater infiltration and the reduction of ET caused by the decrease in green areas in the whole catchment. However, urbanization can lead to localized increases of evapotranspiration in non-urban parts of the catchment, where there are increased groundwater levels due to urbanization in other parts of the catchment. It is therefore important to model the whole groundwater catchment in order to evaluate the 
impact of urbanization and other factors on groundwater levels. Similar results were obtained by Ocampo et al. (2006) who also showed that the groundwater response from a similar catchment in Perth was influenced by a large scale area of the groundwater catchment.

(a) Water balance of the whole catchment

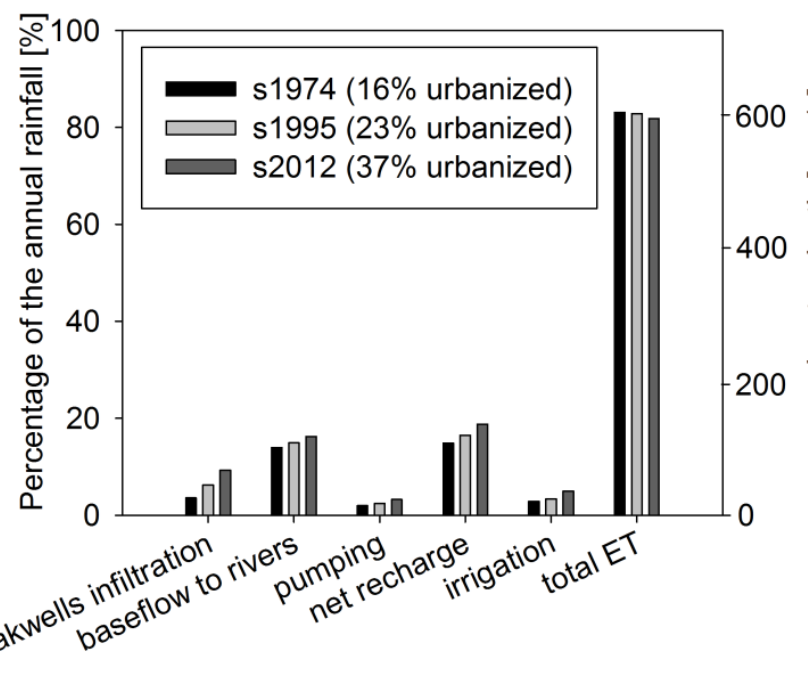

(b) Water balance of the area of Figure $5 \mathrm{~b}$

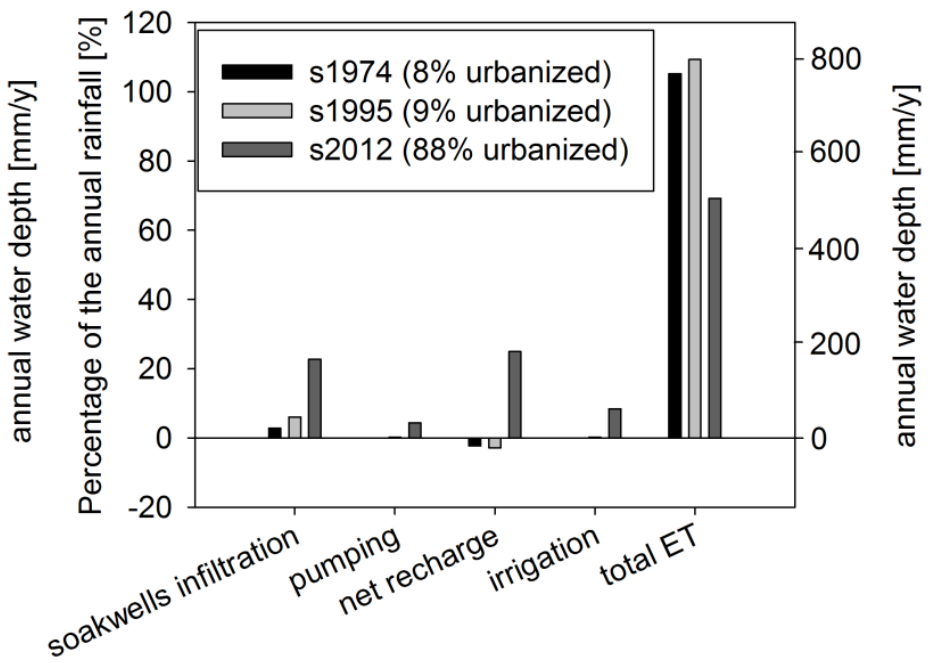

Figure 8. Mean annual water balance for the 2009-2014 period. (a) Water balance of the whole model catchment for the different scenarios. (b) Water balance for the area of Figure 5b. The percent of 'urbanized' area was calculated by summing the land use categories of 'Roads', 'Residential' and 'Dense residential'. Negative 'net recharge' means that the evapotranspiration volume is higher than the rainfall volume in that specific area.

\subsection{Soakwell performance}

Figure 9 shows that the annual overflow volume of soakwells in the model area for the different scenarios for the 2 selected urban areas is less than about $23 \%$ of the incoming rainfall for all the scenarios (corresponding to at least $77 \%$ of annual volume retention). Soakwells in the area were set to have $15 \mathrm{~mm}$ storage resulting in a large annual retained volume. Locatelli et al. (2015) calculated a 99\% annual retention ( $1 \%$ of inflow water overflows annually) for infiltration trenches not affected by shallow groundwater and designed for 1 year return period events in a soil with an average hydraulic conductivity of $4 \cdot 10^{-5} \mathrm{~m} / \mathrm{s}$. This is similar to the overflow estimate (between 0 and $2 \%$ ) obtained in the scenario No_GW of Figure 9. 
Locatelli et al. (2015) showed that stormwater retention decreases significantly when there is groundwater mounding below infiltration trenches. Similar results have been obtained by Machusick et al. (2011) and Roldin et al. (2013). The catchment model presented in this paper does not model localized mounding below the soakwells and the $70 \mathrm{~m} \times 70 \mathrm{~m}$ computational grid cannot capture this localized effect. For this reason the model is likely to overestimate the annual retention in the areas where the groundwater table is less than $2 \mathrm{~m}$ from the bottom of the soakwells ( $3.2 \mathrm{~m}$ below terrain). The $2 \mathrm{~m}$ threshold was obtained by Locatelli et al. (2015) for a soil with an average hydraulic conductivity of $4 \cdot 10^{-5} \mathrm{~m} / \mathrm{s}$. In the model developed here, the conductivity of Bassendean sand high so that the threshold is likely to be less than $2 \mathrm{~m}$ in this model area (Locatelli at al., 2015).

The sub-catchments (Urban areas 1 and 2 of Figure 5a) selected for showing the results in Figure 9 have a stable land use, but the land use around them changes greatly with time. The results from the 3 different land use scenarios (s1974, s1995 and s2012) show a trend of increasing overflow. This suggests that the process of increasing urbanization in the areas surrounding the focus catchments affects the performance of the existing soakwells in the focus catchments. This is because the groundwater levels in the whole model area increase with increasing urbanization and stormwater infiltration.

Soakwell performance is also dependent on their depth below ground, generally the deeper the soakwell, the worse the performance due to the reduced distance to the water table. Moreover the leakage coefficient $C_{L}$ is an influential parameter for the performance of soakwells. This parameters control the infiltration rates (see Eq. 2); the lower the value of $C_{L}$, the lower the infiltration rates and the higher the overflow from soakwells. Time variation of $C_{L}$ due to clogging was not included in the model. The parameter $C_{L}$ was manually calibrated (see Section 2.2).

The soakwell performance is generally overestimated due to the daily rainfall time steps employed in the model, which leads to reduced peak rainfall intensity (e.g. a $20 \mathrm{~mm}$ rainfall that fall in 2 hours can generate a soakwell overflow, however if the $20 \mathrm{~mm}$ rainfall falls over a day the soakwell is likely to not overflow because the daily infiltration rate of soakwells is high). 
Overall, the results of Figure 9 suggest that groundwater dynamics are important for soakwell performance. Locatelli et al. (2015) showed that the annual retention of infiltration trenches decreases with decreasing the conductivity of the soil, and this suggest that the impact of inter-annual groundwater dynamics will be even more significant in areas with lower soil hydraulic conductivity.

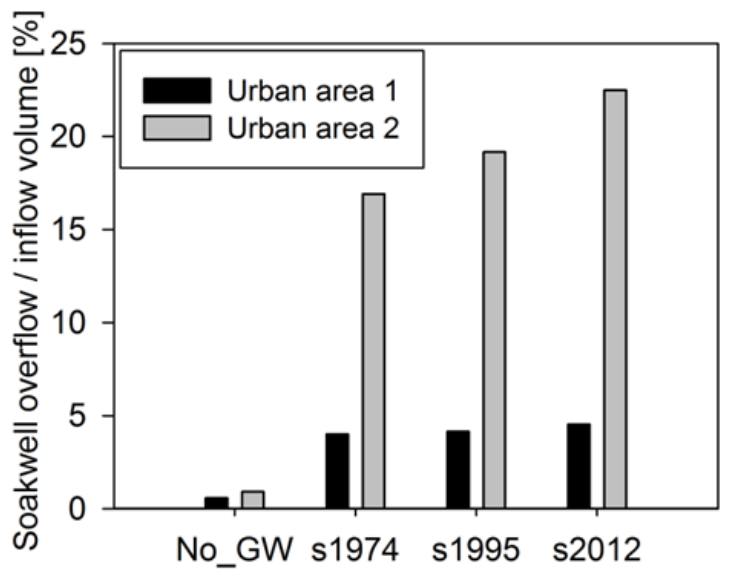

Figure 9. Ratio between the total overflow and the inflow volume for the soakwells in the two different selected urban areas shown in Figure 5a. The horizontal axis shows the different scenarios. The scenario sDrain is not shown since it includes no soakwells.

\subsection{Groundwater rise}

Figure 10 shows the annual maximum groundwater levels as a function of the return period at the observation well CoG11 (see Figure 3c). Overall, each scenario shows a similar trend, and the annual maximum groundwater levels increase with increasing urbanization. This means that the process of urbanization (that reduces evapotranspiration, increases stormwater infiltration and adds irrigation) leads to an increased risk of groundwater flooding. The sDrain scenario (with 2012 land use) shows groundwater heads about $0.4 \mathrm{~m}$ lower compared to the scenario s2012. The scenario sDrain assumed that the stormwater runoff from roofs was removed from the model. Overall results show a significant impact due to stormwater runoff infiltration and reduced evapotranspiration over impermeable areas.

The different land use scenarios (s1974, s1995 and s2012) show annual maximum groundwater level rise due to subsequent urbanization. The area around the CoG11 observation well was not urbanized in both 
the s1974 and s1995 scenarios, but an increase in groundwater levels was observed. This suggests that groundwater levels at CoG11 are influenced by changes occurring in the surrounding area.

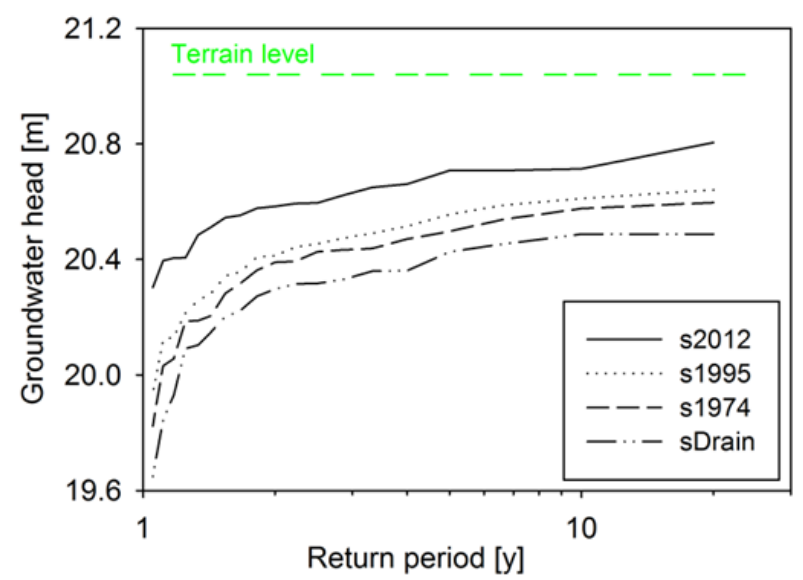

Figure 10. Annual maximum groundwater head at the location of the CoG11 observation well for the different scenarios.

The model outputs shown in Figure 10 can be useful to evaluate the impact of land use changes, due to new buildings/infrastructure and vegetation changes. These outputs could be useful in setting criteria for land planning, helping inform design processes and policy.

\subsection{Water above terrain}

Figure 11 shows the simulated water level above terrain at the Auckland Parade detention basin together with its aerial photos at different dates. This basin is located within an urbanized residential area near the CoG8 and CoG12 wells shown in Figure 6. The aerial photos show that the basin is dry on the $8^{\text {th }}$ May but that water is above terrain the $29^{\text {th }}$ of May, the $1^{\text {st }}$ of August and the $29^{\text {th }}$ of September. The modelled hydrographs show similar patterns of flooding on these dates. This suggests that surface water observed in the catchment is likely due to groundwater rise above terrain levels. Antia (2008) also showed that stormwater infiltration leads to increased groundwater rise to levels above terrain. 


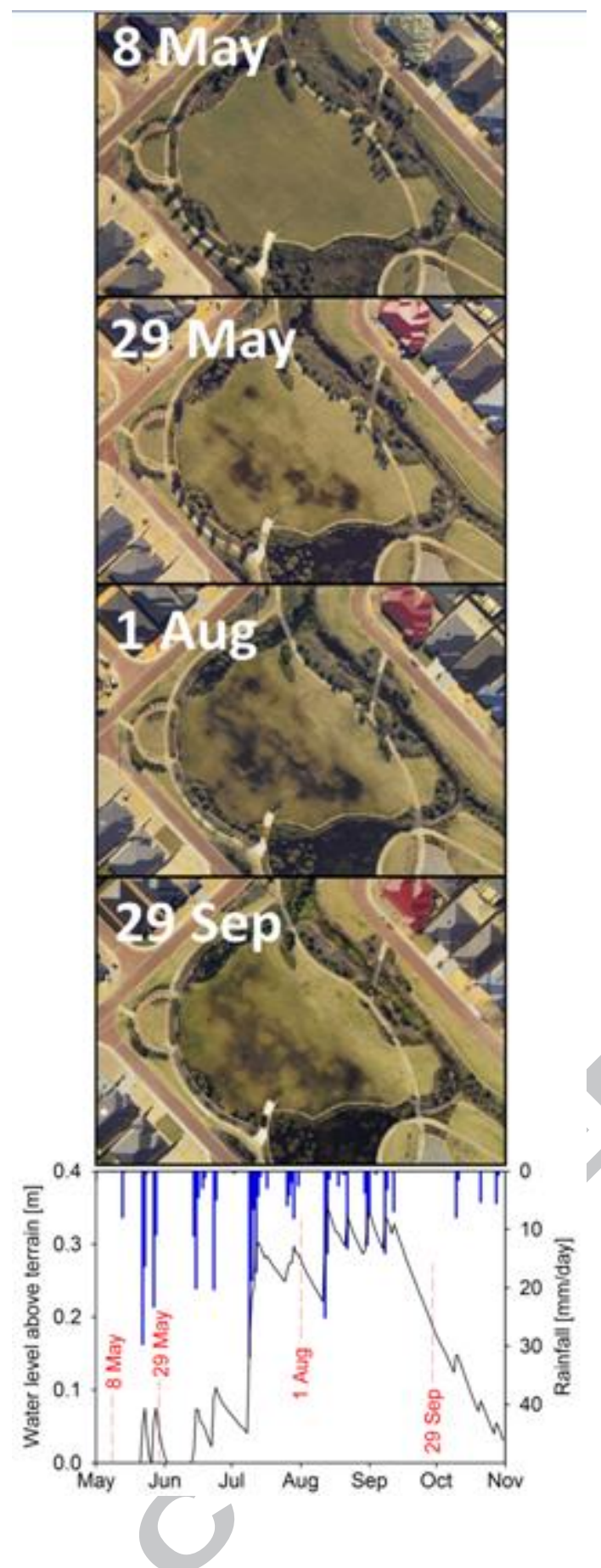

Figure 11. Aerial photos together with the simulated water level above terrain at the Auckland Parade detention basin during the year 2010. The aerial photos show water standing on the green area of the Auckland Parade.

\section{MODEL LIMITATIONS}

\section{Single event response}

The model was designed for long term simulation of changed land use and captures annual trends, but does not reproduce the dynamics of single events. Figure 12 shows an example of simulated and observed 
heads for a number of rainfall events. The daily groundwater observations collected at the CoG and SR wells (Figure 3c) clearly show short term groundwater responses driven by the rainfall, with sharp peaks and fast groundwater recessions that were not fully captured by the model. Daily groundwater observations were used for the calibration, but only 6 observation wells (CoG wells) recorded daily measurements, while the others recorded data with monthly or longer time steps. A calibration using only the $6 \mathrm{CoG}$ observation wells with 24 hour data was attempted without significant improvements. This is because the seasonal groundwater patterns dominate the calibration objective function. Other methods were tested to capture the single event response but without satisfactory results. For instance the computational grid was decreased to $30 \mathrm{~m}$ x $30 \mathrm{~m}$; uniformly distributed groundwater drainage using different drain conductivities was simulated; specific yield and specific storage were reduced to try increasing the groundwater gradients. Crosbie et al. (2005) showed an increase in head changes in response to rainfall as the groundwater becomes shallower. For shallow water tables, the capillary zone extends all the way to the ground surface, decreasing the specific yield); macro-pore flow was introduced to give recharge even if the unsaturated zone storage was not full.

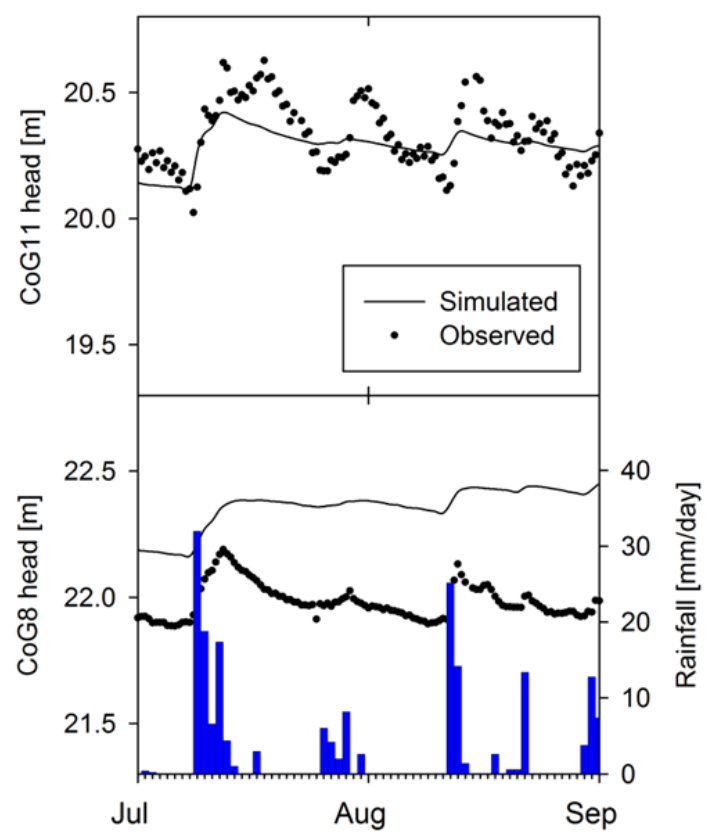

Figure 12. Example of simulated and observed groundwater head for 2 observations wells in 2010.

\section{Long term observed groundwater response}


A minority of the 40-year-long groundwater observation wells ( 3 out of 24 observation wells) in the model area (i.e. 4695, 4676, 4785, see Figure 6) show an overall decreasing trend in groundwater levels that is in contrast with our conclusion that urbanization leads to an overall increase of groundwater levels. The decreasing trends can be caused by the vicinity of observation wells to abstraction wells or other factors like long term decreasing rainfalls. The 70m x 70m model cannot reproduce the local drawdown around abstraction wells. Moreover, abstraction wells for irrigation purposes were modeled as uniform spatially distributed abstraction rates so that the model could not simulate the local drawdown around single abstraction wells. This model did not analyze the effect of long term rainfall variations. As stated in Section 2.1, the south-west of the Western Australia region has experienced decreasing annual precipitations. Moreover, other processes like the change in long term water abstraction and construction of draining channels were not simulated.

The simulated processes associated with urbanization included increased stormwater infiltration, reduced evapotranspiration due to a reduction of green areas, increased abstraction of water for non-potable uses and supply of irrigation. Nevertheless, many other processes were not included. For instance, leakage of freshwater from pressurized water supply networks was not modeled, even though many studies showed that it can significantly contribute to groundwater recharge (Jeppesen, 2010; Yang et al., 1999; VázquezSuñé et al., 2005; Giudici et al., 2001).

\section{CONCLUSIONS}

This study presents a calibrated and validated hydrological model to analyze the catchment scale impact of urbanization with stormwater infiltration on groundwater levels and water balance and the performance of soakwells in the presence of a shallow groundwater. The novelty of this paper is the use of groundwater head observations from a large catchment with gradual urbanization including widespread stormwater infiltration.

Different land use scenarios were implemented to analyze the hydrologic impact of urbanization with stormwater infiltration. This study showed that increasing the degree of urbanization with stormwater 
infiltration caused a rise in groundwater levels due to changes in the water balance, particularly an increased recharge from stormwater infiltration systems and a reduced evapotranspiration due to construction of new impervious surfaces over previously green areas. These changes in the water balance and groundwater levels lead to an increased risk of groundwater flooding due to groundwater seepage above terrain. This study also showed that local changes of land use affect the whole catchment, i.e. the development of new urban areas with stormwater infiltration was shown to cause an overall groundwater rise in the catchment that affected both the water balance and the performance of stormwater infiltration systems in other parts of the catchment that were not affected by land use changes.

The majority of the annual stormwater runoff volume from impervious areas like roofs and roads was shown to be infiltrated through soakwells and surface water system. However, the infiltration capacity of soakwells was shown to decrease with increasing urbanization due to an overall rise of the groundwater table. Seasonal fluctuations of the groundwater table above the bottom of the soakwells were shown to reduce their performance. Therefore, it is relevant to consider the impact of groundwater when modeling stormwater infiltration systems in the presence of a shallow groundwater.

This study highlights the importance of investigating the long term changes in the catchment water balance due to urbanization and the influence of this on the groundwater regime. For the study area of Perth, as well as all other urban development areas in Western Australia, the Department of Water requires an evaluation of groundwater impacts in development proposals (Department of Water, 2013).

\section{Acknowledgments}

The authors thank the Danish Council for Research that financed the present research through the project BIV (Byer i Vandbalance/Cities in water balance) and the Department of Water in Perth, particularly Krish Seewray, Joel Hall and Belinda Quinton for providing the data and comments on the paper. 


\section{References}

Allen, A.D., 1976. Outline of the hydrogeology of the superficial formations of the Swan Coastal Plain: Western Australia Geological Survey, Annual Report 1975, p. 31-42.

Anderson, H.E., Woessner, W.W., 1992. Applied Groundwater Modeling. Academic Press, San Diego, CA.

Antia, D.D.J., 2008. Prediction of overland flow and seepage zones associated with the interaction of multiple infiltration infiltration devices (cascading devices). Hydrological Processes 22(14): 25952614.

AutoCal, 2012. Auto Calibration Tool; User Guide. Dhi Water \& Environment. In: Agern Allé 5, Hørsholm, Denmark.

Barr, A., Barron, O., 2009. Application of a coupled surface water-groundwater model to evaluate environmental conditions in the Southern River catchment. CSIRO: Water for a Healthy.

Barron, O.V., Barr, A.D., Donn, M.J., 2013a. Effect of urbanisation on the water balance of a catchment with shallow groundwater. J. Hydrol. 485, 162-176.

Barron, O.V., Donn, M.J., Barr, A.D., 2013b. Urbanisation and shallow groundwater: predicting changes in catchment hydrological responses. Water Resour. Manage 27 (1), 95-115.

Bergman, M., Hedegaard, M.R., Petersen, M.F., Binning, P., Mark, O., Mikkelsen, P.S., 2011. Evaluation of two stormwater infiltration trenches in central Copenhagen after 15 years of operation. Water Science and Technology 63(10), 2279-2286.

Botte, M., Tennkoon, A., Kannangara, D., 2012. A decade of sustainable stormwater management approaches - do we need to go back to basics? IPWEA, State conference 2012.

Bouwer, H., 2002. Artificial recharge of groundwater: hydrogeology and engineering. Hydrogeology Journal 10(1): 121-142.

Browne, D., Deletic, A., Mudd, G.M., Fletcher, T.D., 2008. A new saturated/unsaturated model for stormwater infiltration systems. Hydrological Processes 22(25): 4838-4849. 
Browne, D., Deletic, A., Mudd, G.M., Fletcher, T.D., 2012. A two-dimensional model of hydraulic performance of stormwater infiltration systems. Hydrological Processes.

Carleton, G.B., 2010. Simulation of groundwater mounding beneath hypothetical stormwater infiltration basins, U.S. Geological Survey. Scientific Investigations Report 2010-5102.

Crosbie, R.S., Binning, P., and Kalma, J.D., 2005, A time series approach to inferring groundwater recharge using the water table fluctuation method: Water Resources Research, v. 41.

Davidson, W.A., 1995. Hydrogeology and groundwater resources of the Perth region Western Australia. Geological survey of Western Australia, Department of minerals and energy.

Department of Water, 2007. Wungong Brook Catchment Area Drinking Water Source Protection Plan. Integrated Water Supply System. Report No. WRP 65. February 2007.

Department of Water, 2004-2007. Stormwater Management Manual for Western Australia.

Department of Water, 2009. Strategic policy 2.03 - Managing unlicensed groundwater use.

Department of Water, 2013. Water resource considerations when controlling groundwater levels in urban development.

DHI, 2012. Collection System. User Manual, DHI Water \& Environment. Agern Allé 5, Hørsholm, Denmark.

DHI, 2012. MIKE 11. A modelling system for Rivers and Channels User Manual, DHI Water \& Environment. Agern Allé 5, Hørsholm, Denmark.

DHI, 2013. MIKE SHE User Manual, Volume 2: Reference guide, 2012. DHI Water \& Environment. Agern Allé 5, Hørsholm, Denmark.

Dietz, M. E., 2007. Low impact development practices: A review of current research and recommendation for future direction. Water Air and Soil Pollution 1-4(186): 351-363.

Duchene, M., McBean, E.A., Thomson, N.R., 1994. Modeling of Infiltration from Trenches for StormWater Control. J. Water Resour. Planning Manage.-Asce 120, 276-293.

Dussaillant, A., Wu, C., Potter, K., 2004. Richards equation model of a rain garden. J. Hydrol. Eng. 9 (3), 219-225. 
Elliott, A.H., Trowsdale, S.A., 2007. A review of models for low impact urban stormwater drainage. Environ. Modell. Softw. 22 (3), 394-405.

Elliott, A.H., Trowsdale, S.A., Wadhwa, S., 2009. Effect of aggregation of on-site storm-water control devices in an urban catchment model. J. Hydrol. Eng. 14 (9), 975-983.

Endreny, T., Collins, V., 2009. Implications of bioretention basin spatial arrangements on stormwater recharge and groundwater mounding. Ecol. Eng. 35 (5), 670-677.

Fletcher, T.D., William, S., Hunt, W.F., Ashley, R., Butler, D., Scott, A.,Trowsdale, S., Barraud, S., Semadeni-Davies, A., Bertrand-Krajewski, J.L., Mikkelsen, P.S., Rivard, G., Uhl, M., Dagenais, D., Viklander, M., 2015. SUDS, LID, BMPs, WSUD and more - The evolution and application of terminology surrounding urban drainage. URBAN WATER JOURNAL, 12(7), 525-542.

Giudici, M., Colpo, F., Ponzini, G., Romano, E., Parravicini, G., 2001. Calibration of groundwater recharge and hydraulic conductivity for the aquifer system beneath the city of Milan (Italy), in Impact of Human Activity on Groundwater Dynamics, Proceedings of a symposium held during the Sixth IAHS Scientific Assembly at Maastricht, The Netherlands, July 2001, 43-50, IAHS Publ. no. 269.

Göbel, P., Stubbe, H., Weinert, M., Zimmermann, J., Fach, S., Dierkes, C., Kories, H., Messer, J., Mertsch, V., Geiger, W.F., Coldewey, W.G., 2004. Near-natural stormwater management and its effects on the water budget and groundwater surface in urban areas taking account of the hydrogeological conditions. J. Hydrol. 299, 267-283.

Guo, C.Y., 1998. Surface-subsurface model for trench Jeppesen, J., 2010. Quantitative Hydrological Effects of Urbanization and Stormwater Infiltration in Copenhagen, Denmark. PhD Thesis. Department of Earth Sciences, Aarhus University, Denmark. JDA Consultant Hydrologists, 2015. Rivergums, Baldivis: Rainfall Runoff Testing. Cedar Woods Properties Limited. 
Kidmose, J., Troldborg, L., Refsgaard, J.C., Bischoff, N., 2015. Coupling of a distributed hydrological model with an urban storm water model for impact analysis of forced infiltration. J. Hydrol., 525(0): 506-520.

Kristensen, K.J., Jensen, S.E., 1975. A model for estimating actual evapotranspiration from potential evapotranspiration. Nordic Hydrology 6, 1975, 170-188

Ku, H.F.H., Hagelin, N.W., Buxton, H.T., 1992. Effects of urban storm-runoff control on ground-water recharge in Nassau County, New York. Ground Water 30 (4),

Locatelli, L., Mark, O., Mikkelsen, P.S., Arnbjerg-Nielsen, K., Wong, T., Binning, P.J., 2015.

Determining the extent of groundwater interference on the performance of infiltration trenches: Journal of Hydrology. 529, 1360-1372.

Machusick, M., Welker, A., Traver, R., 2011. Groundwater mounding at a stormwater infiltration BMP. J. Irrigat. Drain. 137, 154-160.

Maimone, M., O’Rourke, D.E., Knighton, J.O., Thomas, C.P., 2011. Potential Impacts of Extensive stormwater Infiltration in Philadelphia. Environ. Eng.

Manglik, A., Rai, S.N., Singh, V.S., 2004. Modelling of aquifer response to time varying recharge and pumping from multiple basins and wells. J. Hydrol. 292, 23-29.

Markussen, L. M., Korsbech, K., Joansson, K., Mikkelsen, P.S., Sønderup, H., Hansen, M.M., Hansen, S.K., 2004. Lokal afledning af regnvand - effekten af et detaljeret projectforslag på Tingbjerg. No. 44 Miljostyrelsen, Miljoministeret.

McArthur, W.M., Bettenay, E., 1960. The development and distribution of the soils of the Swan Coastal Plain, Western Australia: Australia, Commonwealth Scientific Industrial Research Organisation, Soil Publication 16, p. 55.

Mikkelsen, P.S., Weyer, G., Berry, C., Walden, Y., Colandini, V., Poulsen, S., Grotehusmann, D.And., Rohlfing, R., 1994. Pollution from urban stormwater infiltration. Water. Sci. Technol. 29 (1-2), $293-302$. 
Ocampo, C.J., Sivapalan, M., and Oldham, C., 2006, Hydrological connectivity of upland-riparian zones in agricultural catchments: Implications for runoff generation and nitrate transport: Journal of Hydrology, v. 331, p. 643-658.

Peters, C., Keller, S., Sieker, H., Jekel, M., 2007. Potentials of real time control, stormwater infiltration and urine separation to minimize river impacts: dynamic long term simulation of sewer network, pumping stations, pressure pipes and waste water treatment plant. Water Sci. Technol. 56 (10), $1-$ 10.

Petersen, C.O.R., Jacobsen, P., Mikkelsen, P.S., 1994. Design of stormwater infiltration for reduction of combined sewer overflow (CSO). Water Sci. Technol. 30 (1), 53-61.

Revitt, M., Ellis, B., Scholes, L., 2003. Report 5.1 Review of the use of stormwater BMPs in Europe. In: Project under EU RTD 5th Framework Programme. WP5/ T5.1/D5.1. Middlesex University.

Roldin, M., Fryd, O., Jeppesen, J., Mark, O., Binning, P.J., Mikkelsen, P.S., Jensen, M.B., 2012a. Modelling the impact of soakaway retrofits on combined sewage overflows in a $3 \mathrm{Km}^{2}$ urban catchment in Copenhagen, Denmark. J. Hydrol. 452, 64-75.

Roldin, M., Mark, O., Kuczera, G., Mikkelsen, P.S., Binning, P.J., 2012b. Representing soakaways in a physically distributed urban drainage model - upscaling individual allotments to an aggregated scale. J. Hydrol. 414-415, 530-538.

Roldin, M., Locatelli, L., Mark, O., Mikkelsen, P.S., Binning, P.J., 2013. A simplified model of soakaway infiltration interaction with a shallow groundwater table. J. Hydrol. 497, 165-175.

Salama, R.B., Silberstein, R., Pollock, D., 2005. Soils characteristics of the Bassendean and spearwood sands of the Gnangara mound (Western Australia) and their controls on recharge, water level patterns and solutes of the superficial aquifer. CSIRO Land and Water, Private Bag 5, Wembley, WA 6913, Australia.

Sharma, M.L., Pionke, H.B., 1984, Estimating groundwater recharge from measurements of environmental tracers in the vadose zone, in NWWA/US EPA Conference on Characterisation and 
Monitoring of the Vadose (unsaturated) Zone edited by D. M. NIELSEN: December, 1983, Las Vegas, Nevada, Proceedings, p. 799-819.

Stisen, S., Sonnenborg, T.O., Højberg, A.L., Troldborg, L., Refsgaard, J.C., 2011. Evaluation of Climate Input Biases and Water Balance Issues Using a Coupled Surface-Subsurface Model. Vadose Zone Journal, 10(1): 37-53.

Thompson, A., Nimmer, M., Misra, D., 2010. Effects of variations in hydrogeological parameters on water-table mounding in sandy loam and loamy sand soils beneath stormwater infiltration basins. Hydrogeol. J. 18, 501-508.

Vázquez-Suñé, E., Sánchez-Vila, X., Carrera, J., 2005. Introductory review of specific factors influencing urban groundwater, an emerging branch of hydrogeology, with reference to Barcelona, Spain. Hydrogeology Journal 13 (3), 522-533.

Warnaars, E., Larsen, A.V., Jacobsen, P., Mikkelsen, P.S., 1999. Hydrologic behaviour of stormwater infiltration trenches in a central urban area during 2 3/4 years of operation. Water Sci. Technol. 39 (2), 217-224.

Weibull, W., 1939. A statistical theory of strength of materials. Ing. Vetensk. Akad Handl. 151, 1-45.

Wong, T.H.F., Brown, R.R., 2009. The water sensitive city: principles for practice. Water Sci. Technol. $60(3), 673-682$.

Xiao, Q., McPherson, E.G., Simpson, J.R., Ustin, S.L., 2007. Hydrologic processes at the urban residential scale. Hydrol. Process. 21, 2174-2188.

Yang, Y., Lerner, D.N., Barrett, M.H., Tellam, J.H., 1999. Quantification of groundwater recharge in the city of Nottingham, UK. Environmental Geology 38 (3), 183-198. 


\section{Highlights}

- Monitoring data and model used to analyze the hydrologic impact of urbanization

- Groundwater observations used to calibrate a model of urban stormwater infiltration

- Local stormwater infiltration increases groundwater levels throughout a catchment

- Urbanization reduces evapotranspiration from shallow aquifers

- Urbanization alters the water balance and can lead to increased groundwater levels 